OPEN ACCESS

Edited by:

Ralf J. Ludwig,

University of Lübeck, Germany

Reviewed by:

Rudolf Armin Manz,

University of Lübeck, Germany

Giovanni Di Zenzo,

Istituto Dermopatico dell'Immacolata

(IRCCS), Italy

*Correspondence:

Jolien Suurmond

jsuurmond@northwell.edu

tThese authors contributed

equally to this work.

¥These authors share senior authorship.

Specialty section:

This article was submitted to Immunological Tolerance and Regulation,

a section of the journal

Frontiers in Immunology

Received: 11 January 2018

Accepted: 16 February 2018

Published: 05 March 2018

Citation:

Malkiel S, Barlev AN, Atisha-Fregoso $Y$, Suurmond $J$ and

Diamond B (2018) Plasma Cell Differentiation Pathways in Systemic Lupus Erythematosus.

Front. Immunol. 9:427. doi: 10.3389/fimmu.2018.00427

\section{Plasma Cell Differentiation Pathways in Systemic Lupus Erythematosus}

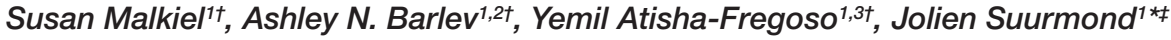 \\ and Betty Diamond ${ }^{1 \neq}$
}

'Center of Autoimmune Musculoskeletal and Hematopoietic Diseases, The Feinstein Institute for Medical Research, Northwell Health, Manhasset, NY, United States, ${ }^{2}$ Donald and Barbara Zucker School of Medicine at Hofstra/Northwell, Hempstead, NY, United States, ${ }^{3}$ Tecnologico de Monterrey, Monterrey, Mexico

Plasma cells (PCs) are responsible for the production of protective antibodies against infectious agents but they also produce pathogenic antibodies in autoimmune diseases, such as systemic lupus erythematosus (SLE). Traditionally, high affinity IgG autoantibodies are thought to arise through germinal center (GC) responses. However, class switching and somatic hypermutation can occur in extrafollicular (EF) locations, and this pathway has also been implicated in SLE. The pathway from which PCs originate may determine several characteristics, such as PC lifespan and sensitivity to therapeutics. Although both GC and EF responses have been implicated in SLE, we hypothesize that one of these pathways dominates in each individual patient and genetic risk factors may drive this predominance. While it will be important to distinguish polymorphisms that contribute to a GC-driven or EF B cell response to develop targeted treatments, the challenge will be not only to identify the differentiation pathway but the molecular mechanisms involved. In B cells, this task is complicated by the cross-talk between the $B$ cell receptor, toll-like receptors (TLR), and cytokine signaling molecules, which contribute to both $\mathrm{GC}$ and $\mathrm{EF}$ responses. While risk variants that affect the function of dendritic cells and T follicular helper cells are likely to primarily influence GC responses, it will be important to discover whether some risk variants in the interferon and TLR pathways preferentially influence EF responses. Identifying the pathways of autoreactive PC differentiation in SLE may help us to understand patient heterogeneity and thereby guide precision therapy.

\section{Keywords: systemic lupus erythematosus, autoantibodies, B cells, plasma cells, tolerance}

\section{INTRODUCTION}

Systemic lupus erythematosus (SLE) is a systemic autoimmune disease characterized by the production of pathogenic autoantibodies that target a variety of nuclear self-antigens, some of which cross-react with tissue antigens. These autoantibodies cause tissue inflammation and lead to organ damage in the kidneys, skin, and more. Presence of IgG ANA is a diagnostic feature

\footnotetext{
Abbreviations: AID, activation-induced cytidine deaminase; BCR, B cell receptor; BM, bone marrow; CSR, class switch recombination; DC, dendritic cell; EF, extrafollicular; FDC, follicular dendritic cell; FO, follicular; GC, germinal center; ICOS, inducible T-cell costimulator; IFN, interferon; MHC, major histocompatibility complex; MZ, marginal zone; PB, plasmablast; PBMC, peripheral blood mononuclear cell; PC, plasma cell; pDC, plasmacytoid dendritic cell; SHM, somatic hypermutation; SLE, systemic lupus erythematosus; Tfh, T follicular helper; TLR, Toll-like receptor.
} 
for SLE and other systemic autoimmune diseases, and these antibodies have an important role in disease pathogenesis $(1,2)$. In contrast, IgM ANA are considered to be protective against autoimmunity. They can be present in healthy individuals and assist in the non-inflammatory clearance of cellular debris and inhibit responses induced by IgG ANA (3-5). Other isotypes include $\operatorname{IgA}$ and $\operatorname{IgE}$, but the pathogenicity of these isotypes has been less well studied.

Antibodies are secreted by plasma cells (PCs), which arise as a terminal differentiation step from B cells. Most of our knowledge of immune tolerance to nuclear antigens, and the break of tolerance in SLE patients, is derived from studies with B cell receptor (BCR)-transgenic mice and single cell studies in humans, where self-reactivity is usually censored in developing B cells prior to their achieving immunocompetence $(6,7)$. Autoreactive cells that escape these mechanisms often become anergic (8-10), a process that mitigates against these cells giving rise to high affinity IgG autoantibody-producing PCs.

Plasma cells can arise through two pathways: through activation of $\mathrm{B}$ cells and direct differentiation in extrafollicular (EF) foci or through a germinal center (GC) response. Although traditionally pathogenic high affinity autoantibodies have been associated with the GC response, recent insights have implicated the EF pathway in SLE as well. We hypothesize that both pathways can contribute to production of SLE autoantibodies. Understanding the regulation of each pathway and how genetic risk alleles may preferentially target one or the other of these pathways will be the focus of this review.

Different subtypes of PCs have been described, including plasmablasts (PB), pre-PC, early PC, short-lived PC, and longlived PC. These terms are sometimes used interchangeably or not clearly defined. The confusion in part derives from the original paradigm that the EF pathway only results in short-lived proliferating PBs, whereas the GC pathway was thought to result only in long-lived quiescent PCs (11). However, lifespan and proliferation can operate independently from each other, such that there are short-lived PCs which are not proliferating, and long-lived PCs from GC origin can proliferate prior to becoming quiescent (12-14). In addition, PC differentiation is a continuum where expression of canonical B cell markers [B220, CD19, major histocompatibility complex (MHC) class II] is gradually lost and PC markers (such as Blimp-1, CD138, secreted Ig) are gradually upregulated (14). It is therefore difficult to define specific PC subsets based on the expression of these markers. Here, we define PCs as antibody secreting cells and we will only mention specific PC subsets if these have been clearly verified. Definitions used in this review are PBs, if proliferation has been verified; short-lived plasma cells, if a short lifespan of $<7$ days has been shown; or long-lived PC, if a long lifespan of $>28$ days has been demonstrated.

\section{T-INDEPENDENT B CELL ACTIVATION AND PC DIFFERENTIATION}

The B cell lineage consists of several subsets and cells diverge early in development. Each of these naive cell subsets can give rise to PCs, but they each preferentially respond to specific types of antigen. Antigens can activate B cells in a T-independent or $\mathrm{T}$-dependent manner. T-independent responses do not require cognate $\mathrm{T}$ cell help. T-independent activation therefore leads to plasma cell differentiation in the absence of GCs. There are two types of $\mathrm{T}$-independent antigens that can induce activation of B cells; TI-1 antigens can activate B cells through coengagement of Toll-like receptors (TLR), such as LPS or other bacterial polysaccharides, whereas TI-2 antigens lead to extensive crosslinking of the BCR, such as polymeric protein antigens or repeated structural motifs (15). In TI-2 responses, competition for antigen enhances the activation and expansion of high-affinity cells, while antigen affinity is less important in TI-1 responses (16).

Although TI-1 and TI-2 antigens have been considered to induce $\mathrm{T}$ cell-independent responses, it is now clear that this distinction is not absolute: TI- 2 and possibly TI- 1 antigens can induce a transient GC (17), and the TI-2 serum antibody responses, in particular IgG, can still be T cell-dependent, even if the antigen cannot directly trigger T cells through MHC class II (18). It has therefore been proposed that the characteristics of the antigen is not the leading determinant of the response, but rather the B cell subset and the ancillary cell types involved determine the nature of the response (19).

In addition to the strength of the initial stimulus through the $\mathrm{BCR}$ and cognate and non-cognate $\mathrm{T}$ cell interactions, $\mathrm{B}$ cell activation is also modified by the presence of other potent stimuli. Pattern recognition receptors, such as TLRs, interact with damageassociated molecular patterns or highly conserved microbial structures present in bacteria or virus. Included among these are both dsDNA (CpG enriched) and RNA. Many TLRs signal through MyD88, and MyD88-deficient mice have diminished antibody responses, both early and late after immunization (20-23). Simultaneous engagement of the BCR and TLRs has a synergistic effect on signaling and subsequent B cell activation (24).

Cytokines, such as type I interferon (IFN), IL-6, and BAFF, can activate $\mathrm{B}$ cells and enhance both T-independent and T-dependent activation (25-27). BAFF has three recognized receptors, and one of them, TACI, signals through MyD88 (28), the same adaptor used by TLR7 and TLR9. Antigen-presenting cells, such as dendritic cell (DC) and macrophages, induce CD40-independent $\mathrm{PC}$ differentiation through secretion of cytokines such as BAFF and APRIL (26).

Two processes that alter the antibody response are somatic hypermutation (SHM) and class switch recombination (CSR), both of which are mediated by the enzyme activation-induced cytidine deaminase (AID) (29). These processes can change antigen recognition by the $\mathrm{BCR}$ (SHM) or change the isotype that is expressed (CSR), and are usually associated with GC responses (discussed below). Although T-independent responses are usually associated with the IgM isotype, CSR can occur in certain infections and does not require cognate T-B interactions (30). CSR can be driven by MyD88 signaling or cytokines such as BAFF, APRIL, IFN-gamma, and IL-21 (20, 23, 31, 32).

\section{B-1 Cells}

B-1 cells represent a distinct population of B cells that arises during fetal development $(33,34)$. They are mainly found in the 
peritoneal and pleural cavities of mice and are rare in lymphoid organs and blood (Figure 1) (35). B-1 cells generally express germline-encoded, polyreactive $\operatorname{IgM}$ and $\operatorname{IgA}$ antibodies with limited V-gene segment usage, and are activated by T-independent antigens, such as LPS (TI-1) or multivalent antigens (TI-2) (36-38). In mice, B-1 cells can be further divided into B-1a and $\mathrm{B}-1 \mathrm{~b}$ according to the expression of CD5 (CD5+ or CD5-, respectively). B-1a cells have been proposed as a major source of natural autoantibodies (37-40). These low-affinity polyreactive antibodies can be secreted spontaneously and are important in the clearance of apoptotic debris. They also contribute to protection against pathogens such as Streptococcus pneumoniae and influenza $(41,42)$. B-1b cells respond primarily to T-independent antigens (TI-1 and TI-2) and generate IgM memory cells, which contribute to protection against reinfection with Borrelia hermsii, S. pneumoniae, and Salmonella (19, 41, 43-45).

B-1 cells are poor at forming GCs (46); however, class-switched, somatically mutated B-1 antibodies showing evidence of antigen selection have been isolated from humans (47). Although elevated numbers of B-1 cells are present in some lupus-prone mouse strains $(36,48)$, there is not a clear association with SLE $(49,50)$.

\section{Marginal Zone (MZ) B Cells}

Marginal zone and follicular (FO) B cells differentiate from transitional B cells and both can participate in T-dependent and $\mathrm{T}$-independent immune responses. MZ B cells are located in the $\mathrm{MZ}$ of the spleen, where they can serve as a first line of defense to T-independent and blood-borne antigens, such as lipopolysaccharide from bacteria (51). They are characterized by high responsiveness to TLR activation, as well as a preactivated state with high expression of complement receptors and costimulatory molecules. Due to these characteristics, they are known for their ability to quickly differentiate into PCs in response to T-independent antigens (51-53). MZ B cells do not require cognate $\mathrm{T}$ cell help, as soluble factors such as cytokines and costimulation derived from DCs, neutrophils, iNKT cells, and $\mathrm{T}$ cells, can also lead to their activation, CSR, and differentiation into PCs $(28,31,54,55)$.

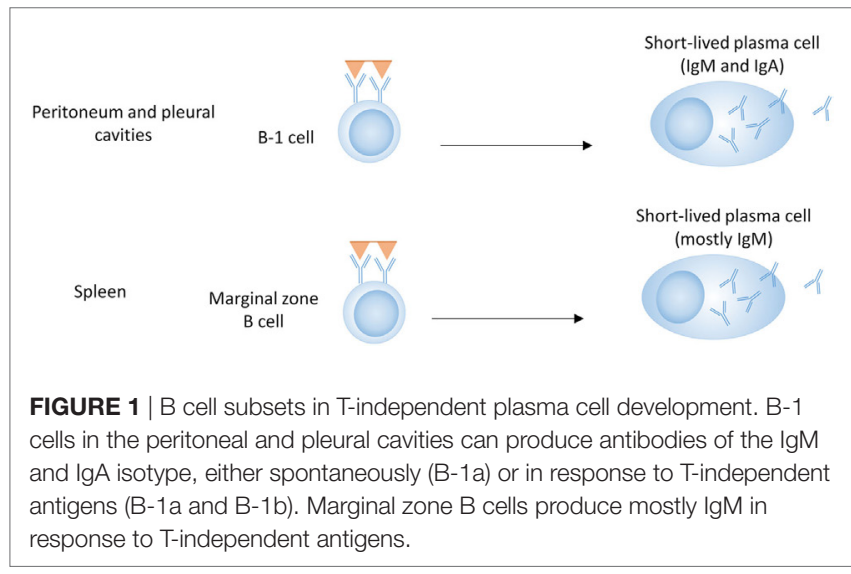

\section{FO B Cells}

Follicular B cells are migratory cells that move between lymph nodes, splenic follicles and the circulation until they interact with antigen. While MZ B cells are specialized in the response to $\mathrm{T}$-independent antigen, they can also transport these antigens to the follicles and transfer such antigens to FO B cells $(56,57)$. However, compared to MZ B cells which become blasts within $24 \mathrm{~h}$ of mitogen activation, FO B cells do not show blast formation in response to mitogen, due to their requirement for cognate $\mathrm{T}$ cell help, and therefore the contribution of FO B cells in T-independent responses is probably limited (51).

\section{T-CELL-DEPENDENT ACTIVATION OF B CELLS}

Although there are models where T-independent responses can contribute to lupus in mice $(58,59)$, the majority of studies in lupus-prone mice and SLE patients suggest that $\mathrm{T}$-dependent responses are the main driver of the disease. Therefore, we will focus on T cell-dependent responses for the remainder of this review. Here, we will first discuss the initial activation of $\mathrm{B}$ cells in a $\mathrm{T}$-dependent response, including the cell fate decisions into either the EF or the GC pathway, followed by a discussion of the PC differentiation pathways after they diverge.

T-dependent responses are thought to be dominated by FO $\mathrm{B}$ cells, although MZ B cells can migrate to the T-B border, activate T cells, and enter a GC (60-63). Although it is unclear how much they contribute to class-switched GC-derived antibody responses, MZ B cells can certainly contribute to T-dependent EF responses (Figure 2) $(64,65)$. MZ B cells can also capture and deliver blood borne antigens to the follicles, thereby enhancing T-dependent FO responses (66). This indicates that although MZ B cells do not require cognate $\mathrm{T}$ cell interactions for their differentiation into PCs, they can still participate in T-dependent responses (Figure 2).

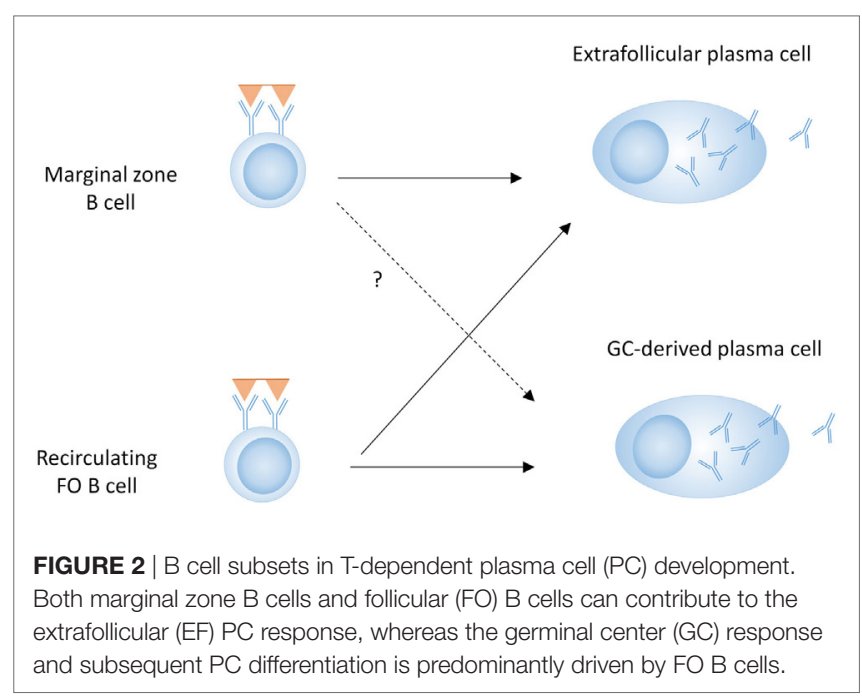


Recirculating FO B cells are activated by antigen in peripheral tissues or in lymphoid tissue where they encounter soluble antigen or antigen arrayed on follicular dendritic cells (FDCs). Activated B cells upregulate chemotactic factors (CCR7, EBI2) that favor their migration to the B-T border in the lymph nodes or spleen $(67,68)$. At the same time, CD4+ $\mathrm{T}$ cells are activated by DCs in the $\mathrm{T}$ cell zone, and these activated $\mathrm{T}$ cells will also migrate to the $\mathrm{B}-\mathrm{T}$ cell border. The differentiation of Th cells [Th1, Th2, Th17, T follicular helper cells (Tfh)] is determined by T cell-DC interactions and is driven by the engagement of pattern recognition receptors by pathogens- or damage-associated molecules (69). At the T-B border, cognate interactions between antigen-specific $B$ and $T$ cells drives initial proliferation, and some $B$ cells will undergo immunoglobulin CSR under the influence of T cell-derived cytokines (60, 70-73).

After activation, B cells can diverge into EF PCs and GC $\mathrm{B}$ cells. While it is well known which transcription factors drive the differentiation into GC B cells versus EF PCs, whether there is direct competition between EF and GC differentiation has not been fully demonstrated. Since B cells can proliferate at the T-B border prior to making cell-fate decisions, it is possible that the distinction between cells with the same high affinity that enter an EF or a GC pathway is partly stochastic and that the same B cell clone can be found in both pathways $(74,75)$.

Under non-competitive conditions, low-, medium-, or highaffinity B cells can all seed a GC, whereas the low-affinity cells are unable to generate an $\mathrm{EF}$ antibody response (76), due to failure to expand low-affinity EF PCs rather than a lack of initiation of PC differentiation (75). In contrast, under competitive conditions, low-affinity cells compete with high affinity cells and are unable to expand or enter a GC response (77). The advantage of high affinity B cells in each response can be at least partly explained by the degree of T cell help that is received, as high affinity B cells stimulated with antigen express higher amounts of MHC class II in the membrane, and are able to present more peptide to $\mathrm{T}$ cells, establishing a more effective immunological synapse (77), which can affect both EF and GC responses.

Although TLR activation during T-independent responses clearly increases the magnitude of the EF response, TLR ligation in $\mathrm{T}$-dependent responses can enhance both the GC response and the EF response (22), in a B cell-extrinsic or -intrinsic manner (78).

\section{PC DIFFERENTIATION}

\section{PC Differentiation in EF Responses}

As EF PCs can provide an initial wave of secreted antibodies during the first week of an infection, these cells are an important part of the initial antibody response against pathogens (11). During expansion at the T-B border, those cells destined to become EF PCs will upregulate Blimp-1, CD138, and CXCR4 (79). Differentiation of EF PCs is driven by T-B interactions with a specific subset of Th cells that resembles Tfh cells but is located in EF areas. These Th cells are dependent on Bcl-6 and Stat3, and their interaction with B cells is mediated through CD40-CD40L and inducible T-cell costimulator (ICOS)-ICOSL interactions as well as cytokines, such as IL-21 $(75,79,80)$. These interactions lead to heavy chain CSR as well as initiation of PC differentiation (Figure 4).

Under the influence of CXCR4, EF PCs migrate to the red pulp, where they can further proliferate and differentiate in EF foci. Proliferation is driven by BCR signaling, as cells with high affinity BCRs have increased proliferation and decreased apoptosis compared to cells with low affinity BCRs (75). Cofactors, such as CD19 and other molecules that enhance BCR signaling, can enhance EF proliferation. Lyn, an inhibitory molecule in the BCR signaling pathway, can diminish proliferation while in fact driving terminal PC differentiation (16). After the proliferative stage, $\mathrm{PBs}$ will differentiate further into PCs, characterized by higher expression of Blimp-1, further loss of MHC class II and costimulatory molecules. However, as discussed below, many EF PBs are short-lived and die prior to full differentiation into PCs (75). Some, however, complete their PC differentiation, after which they can survive in specialized niches in the spleen or bone marrow (BM) $(12,14)$.

Recent evidence suggests that several characteristics previously attributed to GC responses can also occur in EF responses. This includes the formation of memory B cells, CSR, SHM, and induction of long-lived PCs (discussed below). Whereas the previous understanding was that memory B cells are generated only in the GC, memory cells initially appear in blood before GC formation (81), and Bcl-6-deficient mice, which are unable to form GCs, generate memory cells (82). Most of these are nonmutated and IgM + memory cells, suggesting an EF origin at least for some memory cells. Although CSR and a low degree of SHM occur during early B-T interactions at the T-B border, continued AID expression and affinity maturation in EF sites has been observed (83).

\section{GC Responses}

Germinal centers are areas of T-dependent B cell development in spleen, tonsils, lymph nodes, and Peyers' patches. FDCs are important for normal splenic architecture and B cell development, as well as for maintaining the structure and function of the GC (84). Importantly, they capture antigen in immune complexes and retain the antigen in native form. Antigens are presented by FDCs on the cell surface (85). Several sequential events are involved in the formation of the GC. At the T-B border, B cell and $\mathrm{T}$ cell encounter with antigen stimulates formation of a GC (86), and migration from the T-B border into the follicle is mediated by CXCR5 (87). B cells receiving more T-help are more prone to differentiate into GC B cells $(88,89)$, and T cells differentiate into Tfh under the influence of B cell costimulatory molecules, including OX40L and CD80, which are essential for the maturation of Tfh cells $(90,91)$. The transcription factor Bcl-6 is required for the development of both GC B cells and Tfh cells (92). Tfh cells are specialized $\mathrm{T}$ helper cells that are involved in the selection and survival of B cells in the GC. The canonical costimulatory signal involved in the B-T cell interaction in the GC is CD40-CD40L $(93,94)$, but other signals such as ICOS-ICOSL, and IL-21 produced by Tfh cells are also required $(95,96)$.

The structure of the GC, with a light zone and a dark zone, aligns with the processes of SHM, affinity maturation, and selection (Figure 5). B cells in the light zone are referred to as 
centrocytes. They interact with FDCs through antigen and with Tfh cells through MHC-peptide interactions (97). Those B cells which make stronger interactions with Tfh cells, due to an increased $\mathrm{T}$ cell receptor peptide-MHC interaction, are positively selected and enter the dark zone where their proliferation is greater $(98,99)$. As more antigen is added, the population of $\mathrm{B}$ cells with BCRs that bind antigen sufficiently to induce positive selection increases (99). Positive selection in the light zone is important as it leads to GC B cells with the greatest affinity for antigen. Interactions between Tfh cells, antigen, and B cells in the light zone determine the extent of proliferation in the dark zone (99). Fewer cells move from the light zone to the dark zone than from the dark zone to the light zone indicating that selection occurs in the light zone $(99,100)$.

The dark zone is the location where the most active proliferation of GC B cells takes place, as all GC B cells that are in G2 or M phase are in the dark zone; however, $\mathrm{S}$ phase cells are present in both the light zone and dark zone (100). Proliferation can occur under the influence of mTORC1 kinase, which activates the metabolic program that permits proliferation of B cells in the dark zone (98). After positive selection in the light zone and while undergoing proliferation in the dark zone, SHM occurs to effect a process called affinity maturation. During this process, point mutations occur in the BCR which affect its affinity for antigen. When the B cell returns to the light zone, the $B$ cells that have undergone mutations to enhance affinity for the antigen are preferentially selected (101). A stronger interaction with Tfh cells in the light zone allows the $\mathrm{B}$ cell to undergo more rounds of proliferation in the dark zone. Therefore, each time the cell divides and more mutations are acquired, more affinity maturation can occur for B cells that were most positively selected for in the light zone (99).

Negative selection also occurs in the GC. B cells with weak affinity for antigens in the GC, or autoreactive B cells recognizing ubiquitously expressed self-antigens are eliminated $(102,103)$. Proposed mechanisms for the negative selection of these B cells are Fas-mediated apoptosis of cells that fail to bind antigen, failure to receive continuing $\mathrm{T}$ cell help, or the activity of $\mathrm{T}$ follicular regulatory cells (Tfr) (102). A recent study, however, suggests that negative selection primarily occurs in cells with an unproductive BCR as a consequence of SHM rather than in cells with lower affinity (104).

\section{PC Differentiation in the GC}

Both memory B cells and PCs arise from the GC, and many studies have examined the factors that determine if a given $\mathrm{B}$ cell will become a memory B cell or a PC. High affinity GC B cells become PCs, while lower affinity GC B cells become memory B cells (105-107). The initiation of PC differentiation in the light zone requires strong affinity for antigen; further differentiation in the dark zone requires help from Tfh cells (108). Light zone B cells become memory B cells early in the GC reaction, while PCs are formed later $(105,109)$. Preventing apoptosis in the GC allows for lower affinity B cells to become memory B cells but does not change the development of PCs, further suggesting that selection of B cells into the PC population is dependent on high affinity for antigen (106).
Certain cytokines favor the development of PCs. Among them, IL-21 is the most potent inducer of PC differentiation from memory and naive B cells $(110,111)$. This cytokine is produced by Tfh cells in the GC and activates the JAK1/3 STAT3 pathway. IL-21-deficient mice are unable to generate fully functional GCs. Without IL-21 or Tfh cells, PC formation is disrupted, affinity maturation does not occur, and the population of memory B cells is expanded $(91,96,110)$.

Toll-like receptor ligands also enhance GC responses through both DCs and B cells $(21,78,112)$. Whereas soluble TLR ligands can enhance GC responses through an effect on DCs, an antigen that can trigger both endosomal TLRs and BCRs can enhance the IgG antibody response in a B cell-intrinsic manner (21). This probably reflects the requirement for BCR-mediated uptake of ligands for endosomal TLRs in this process, and explains why some studies reported no effect of TLR signaling on GC responses induced with LPS $(113,114)$. B cell-intrinsic MyD88 signaling specifically enhances the formation of GC B cells, affinity maturation, and CSR in response to the TLR-9 ligand CpG coupled to the hapten NP, without affecting the number of PCs. In contrast, MyD88 signaling in DCs contributes to PC differentiation without affecting affinity maturation (78).

Different transcription factors are involved in the differentiation of PCs and memory B cells. Bach2 is reported to be important for selection of GC B cells into memory B cells; in the light zone, $B$ cells with lower affinity for antigen have higher expression of Bach2, probably due to a lower degree of T cell help in those cells $(105,115)$. In addition to Bach2, ABF-1 leads to memory B cell differentiation and prevents PC differentiation (116). The transcription factors Blimp-1, XBP-1, and IRF4 are all involved in PC differentiation (117-119). Blimp-1 leads to decreased expression of genes involved in B cell signaling pathways including Pax5, which in turn leads to increased expression of Blimp-1 and XBP-1. This feed-forward mechanism is needed for PC differentiation (120, 121). Whereas Blimp-1 is required for PC differentiation, XBP-1 is more specifically needed for the unfolded protein response that is required for the production of high amounts of immunoglobulin in PCs (122).

It has been recently reported that $\mathrm{PC}$ differentiation is initiated in light zone B cells after which they migrate to the dark zone to further differentiate (108). Together with simulation data, this suggests that PCs exit the GC through the dark zone (123). Similar to the EF response, GC-derived PCs are characterized by a proliferative $\mathrm{PB}$ stage. Proliferating $\mathrm{PBs}$ have been reported in the dark zone of the GC, as well as the T-B border directly adjacent to the GC $(123,124)$, and their proliferation decreases as they migrate further from the GC, and is completely lost as they reach the medulla of the lymph node or the splenic red pulp (124). This suggests that proliferation of GC-derived PBs occurs during their transit out of the GC, at distinct locations from EF $\mathrm{PBs}$, which proliferate in EF foci mainly in the red pulp of the spleen or the medulla of the LN. Some GC-derived PCs migrate to the red pulp in the spleen or the medullary cords in the lymph nodes, and others migrate through the blood to the BM $(14,81)$. Their exit out of the secondary lymphoid organs occurs prior to completion of their differentiation, as circulating $\mathrm{PBs}$ that arise in 
GC responses in humans show signs of recent proliferation such as expression of $\mathrm{Ki} 67(14,125)$.

\section{PC Survival}

Two studiesin thelate 1990s showed the existence oflong-lived PCs, disputing previous thinking that PCs were short-lived $(126,127)$. A more recent study showed that 10 years after vaccination, longlived PCs were still present in the BM, despite memory B cell depletion (128). Another study shows the survival of these long lived PCs despite CD19 directed CAR T cell therapy (129). These PCs have become a challenge in treatment of SLE, as they are often not eliminated by traditional therapies $(130,131)$. Although most evidence suggests that selection of PCs into the long-lived PC pool is dependent on extrinsic factors $(132,133)$, there is some evidence that B cell-intrinsic factors are also involved $(134,135)$. Identification of intrinsic factors leading to long-lived PC survival could represent therapeutic targets for SLE and other autoimmune diseases.

Plasma cell survival depends on cytokines secreted by stromal cells and eosinophils in the BM $(136,137)$, but they can also survive in the spleen or other organs, particularly under inflammatory conditions. PCs can survive anywhere as long as sufficient survival factors are present (138), but niches have the capacity to support only a limited number of PCs (132). Two related factors important for survival of PCs are BAFF and APRIL, which act through binding to TACI and BCMA (139-141). Both cytokines are anti-apoptotic and increase PC survival (140). A study in autoimmune thrombocytopenia suggests that an increase in BAFF caused by B cell depletion promotes differentiation of short-lived PCs into long lived PCs in the spleen $(142,143)$. Other molecules which can enhance survival of PCs are IL-6, VCAM-1, CXCR4, and CD28 (11, 136, 144).

CD93, a C1q receptor on $\mathrm{B}$ cells, is needed for the survival of PCs in the BM and is expressed only by a subset of PCs in mice (145). Induction of CD93 expression may, therefore, be an example of a B cell-intrinsic factor that contributes to PC survival.

Despite the traditional paradigm mentioned above, there are descriptions of long-lived PCs in T-independent responses, $\mathrm{T}$ cell-deficient, and GC-deficient mice, with survival up to at least 100 days $(12,132,146,147)$. In addition, PCs exit the GC as $\mathrm{PBs}$, and require a survival niche for full differentiation. As many of them fail to find the appropriate niche, not all GC-derived PCs are long-lived (12). As far as we know now, transcription factors that drive PC differentiation in each response are similar, and it is not clear if all PCs have the potential to become long-lived or whether some are selected, preferentially in the GC, to become long-lived, and whether this is accompanied by altered expression of key survival molecules and transcription factors that drive this distinction.

\section{TOLERANCE}

\section{Tolerance in EF Responses}

As autoimmunity has been traditionally thought to arise through the GC, tolerance checkpoints in EF responses have not been extensively studied. Whereas the fast rate of the EF response is needed for adequate responses against pathogens, it also limits the time window for tolerance checkpoints. Therefore, it is likely that autoreactive B cells can be activated during EF responses, either through direct activation by self-antigen in an inflammatory milieu, cross-reactivity with foreign antigen, or through TLR ligands or cytokines (148). However, even if autoreactive PCs are generated in EF responses, they are mostly short-lived limiting the inflammation and tissue damage that is induced by autoantibodies. Therefore, the transient nature of the EF response may itself be a tolerance mechanism.

In addition to the short-lived nature of the response, tolerance in EF responses can be maintained through the balance between IgM and other (more pathogenic) isotypes. As most EF PBs secrete IgM, even though some CSR can occur, the balance between IgG and IgM that is generated in EF responses may result in prevention of autoimmunity, through downregulating myeloid cell activation in a LAIR-1 dependent fashion and minimizing local inflammation $(3,5,149)$. In addition, sialylation of IgG antibodies, which occurs in T-independent responses can also contribute to tolerance, as these antibodies have lower pathogenicity, at least in the context of rheumatoid arthritis [(150), p. 296; (151), p. 429].

$\mathrm{T}$ cell help during initial activation might play a role in tolerance in EF foci, where class-switched EF responses can occur through cytokines secreted by bystander T cells or non-T cells. Since there is no requirement for cognate $\mathrm{T}$ cell help, the $\mathrm{T}$ cell repertoire is unlikely to restrict autoreactivity in the EF response.

\section{Tolerance in GC Responses}

Although the mechanisms of central tolerance preclude many autoreactive B cells from entering GCs, self-reactive B cells developing in the BM can bypass tolerance mechanisms. This may occur if they are reactive to monovalent antigen, if their affinity for antigen is below a certain threshold, or if they are present in an inflammatory milieu $(152,153)$. Therefore, it is normal to have circulating autoreactive mature (naive) B cells (154).

Importantly, however, mechanisms of peripheral tolerance are also in place to further eliminate autoreactivity. Mature selfreactive $B$ cells can be thwarted from entering the follicle and be induced to become anergic (155). Still, some self-reactive B cells are able to enter the follicle. Evidence also suggests that autoreactive $\mathrm{B}$ cells that were initially excluded from the follicle can later be recruited into the $\mathrm{GC}$, at which point these cells undergo SHM which may remove autoreactivity $(156,157)$, but can also lead to enhanced self-reactivity $(153,158)$. One important tolerance mechanism is the short lifespan of these B cells without mitogenic stimulation. Thus, only in an inflammatory milieu are these cells likely to access a GC response.

$\mathrm{B}$ cells that acquire autoreactivity in the GC must be eliminated or prevented from becoming PCs. In the GC itself, several tolerance mechanisms have been described, including apoptosis and receptor editing. However, a recent study showed that autoreactive $\mathrm{GC} B$ cells are not strongly selected to undergo apoptosis, perhaps because so many autoreactive B cells are cross-reactive with an eliciting antigen (104, 159-163). It is conceivable that these tolerance mechanisms are initiated by lack of cognate $\mathrm{T}$ cell 
help. As described, T-cell help is needed for positive selection of $B$ cells into PCs in the GC, and without this help, self-reactive PCs will not develop $(100,102,152,153)$. Thus, although self-reactive memory B cells can develop, the requirement for Tfh cells and FDCs that recognize or present the autoantigen makes it more difficult for non-cross-reactive autoreactive PCs to develop. $\mathrm{T}$ cells recognizing foreign antigen may be able to stimulate autoreactive GC B cells, if the BCR crossreacts with the eliciting antigen or an antigen present in a multimolecular complex with the eliciting antigen.

As IgG + memory B cells in healthy individuals have a much higher frequency of self-reactivity than IgG + PCs (164), an additional tolerance checkpoint must exist that prevents the differentiation of autoreactive PCs in addition to a tolerance checkpoint in GC B cells (Figure 3). Interestingly, switched PCs maintain expression of MHC class II and the antigen presentation machinery required for cognate $\mathrm{T}$ cell interactions at least until they are no longer proliferating, suggesting that this stage of PC differentiation may represent a $\mathrm{T}$ cell-dependent tolerance checkpoint (165). Although this has not been extensively studied, Th cells are required for the completion of GC-derived PC differentiation (103), and PCs can undergo cognate T cell interactions after their migration out of the GC at the T-B border (165). This suggests that a lack of T cell help may prevent the terminal differentiation of autoreactive PCs or that autoreactive B cells committed to becoming PCs are more susceptible to apoptosis or receptor editing than B cells committed to a memory pathway.

\section{PC DIFFERENTIATION IN SLE}

\section{EF PC Differentiation in SLE}

Because there are no definite markers that discriminate PCs based on their pathway of differentiation, it is hard to establish the pathway through which they were derived, especially in humans where access to lymphoid organs is limited. In addition, most studies discriminating EF responses from GC responses use acute immunization models, and it is not clear if all the paradigms that have been proposed for the distinction between EF and GC responses apply in the chronic immune activation present in autoimmune conditions. Although EF PC differentiation in autoimmunity has not been emphasized, recent studies indicate this pathway may have a specific role in autoimmunity $(125,166,167)$. MRL/lpr mice exhibit EF PC generation, although they have increased formation of spontaneous GCs as well $(166,168,169)$. In humans, recent research supports that a large proportion of the PCs in some SLE patients are clonally related to naive cells, suggesting an EF origin (125). Here, we propose mechanisms which can lead to enhanced EF responses in SLE (Figure 4).

\section{Expansion of MZ B Cells}

Marginal zone B cells are expanded in several lupus-prone mouse strains. In humans, the characterization of MZ B cells is much more complicated [reviewed in Ref. (13)], and it is unclear if SLE patients also have an expansion of this population. However, the high BAFF levels often present in SLE patients would support MZ expansion. Mice overexpressing BAFF develop an SLE-like phenotype that is characterized by a high titer of class-switched autoantibodies and PCs, in a T cell-independent manner (59). A preference for autoreactive $B$ cells to differentiate into MZ B cells compared to FO B cells has been described in mice (170-173), and MZ B cells can differentiate directly into IgG + PCs in EF responses $(174,175)$. Therefore, development of serum autoantibodies in some lupus-prone mice has been attributed to $\mathrm{MZ}$ expansion and activation, although some studies have challenged this paradigm (176-180).

\section{Enhanced TLR Signaling}

Another mechanism by which EF PC responses in SLE may be altered is through enhanced TLR signaling. MyD88-deficient $\mathrm{MRL} / \mathrm{lpr}$ mice develop lower autoantibody titers and are

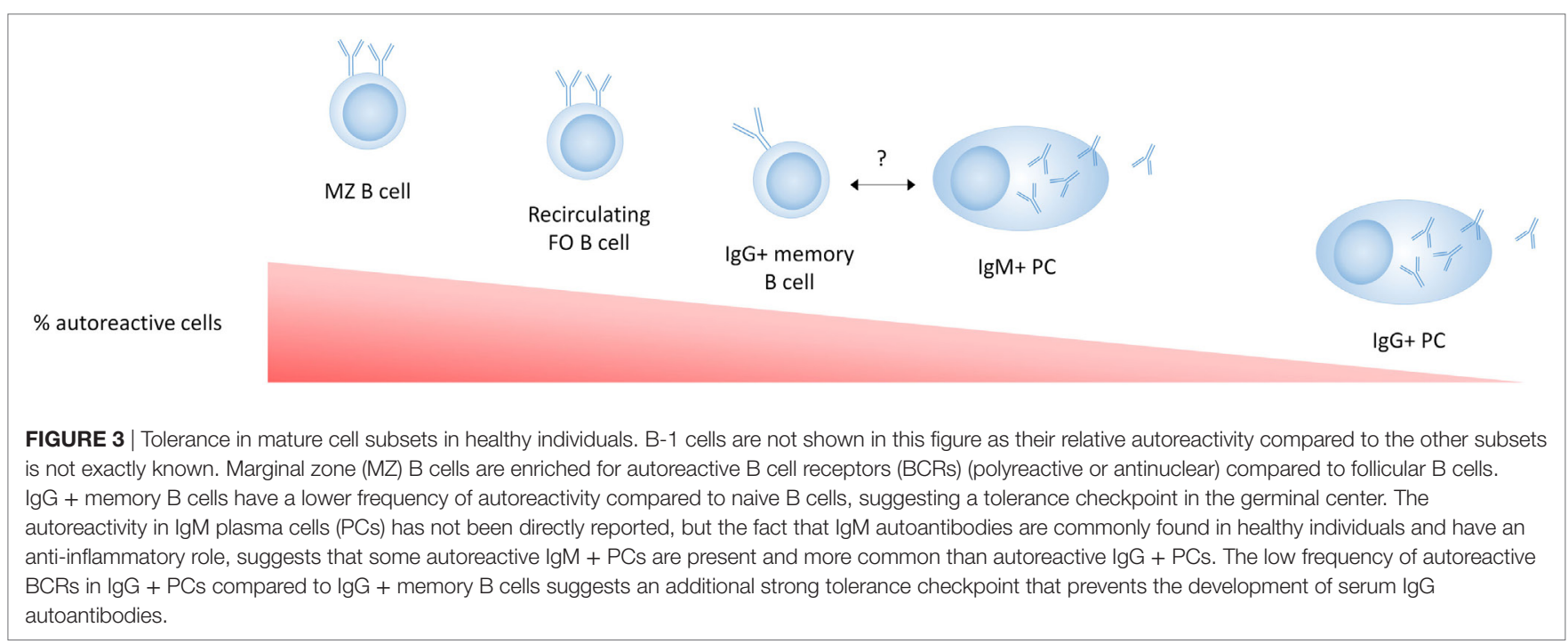




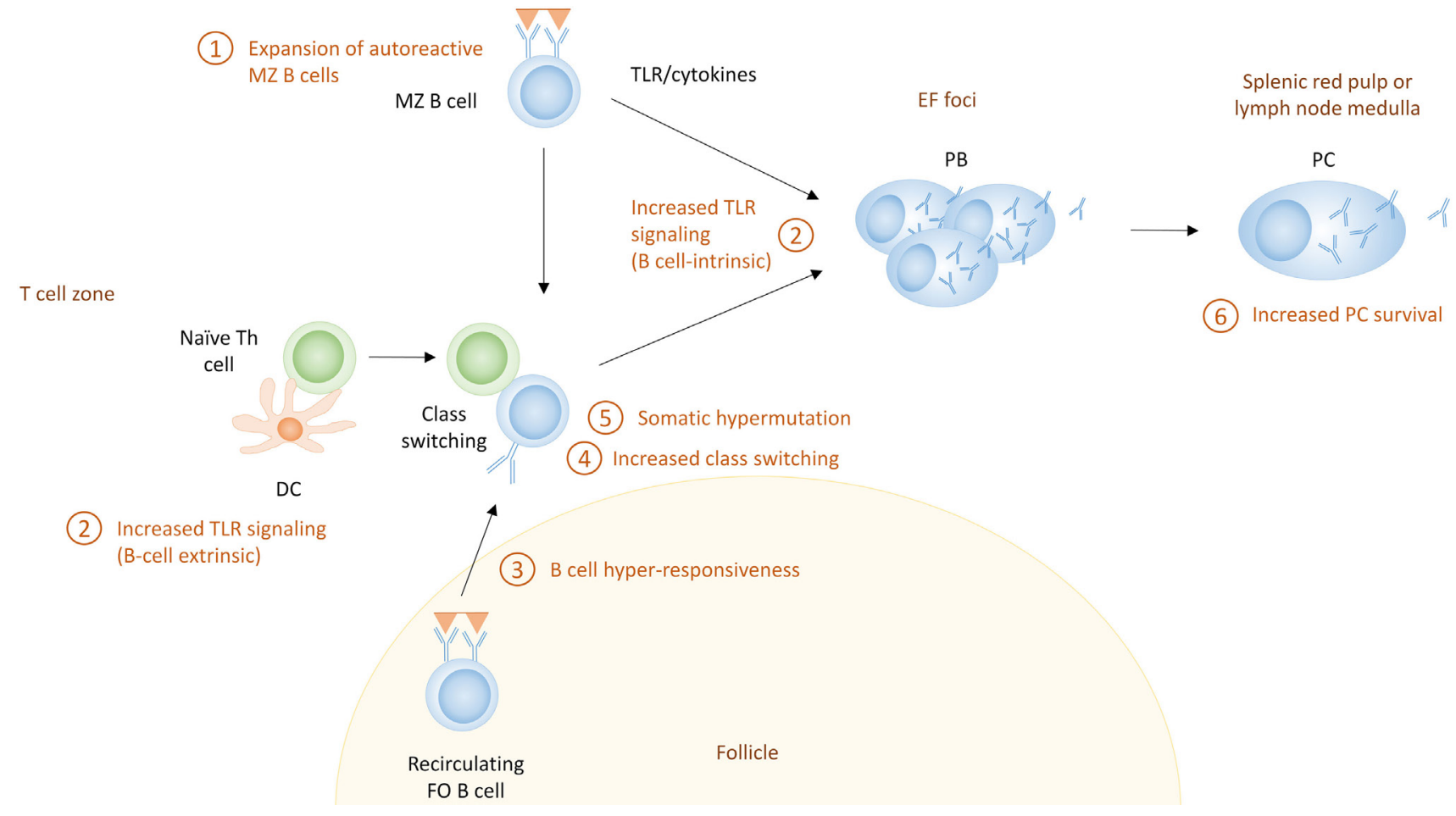

FIGURE 4 | The extrafollicular (EF) pathway for the generation of autoreactive plasma cells (PCs) in systemic lupus erythematosus. Shown here are the potential mechanisms that can contribute to enhanced extrafollicular PC responses. These include (1) expansion of marginal zone (MZ) B cells, which often exhibit autoreactive receptors; (2) increased Toll-like receptor (TLR) signaling, which can directly activate B cells (B cell-intrinsic) or can enhance Th responses through their effect on dendritic cells (B cell-extrinsic); (3) B cell hyperresponsiveness, which can affect the activation of follicular B cells; (4) increased class switch recombination which can lead to more pathogenic IgG autoantibodies; (5) somatic hypermutation which can lead to affinity maturation of autoreactive PCs; and (6) increased PC survival.

protected from disease $(181,182)$, suggesting a role for TLRs in EF responses in MRL/lpr mice. Although TLR-7 or -9 deficiency each diminished the production of specific types of autoantibodies in MRL/lpr mice, only TLR-7 deficiency diminished lymphocyte activation, IgG production, and kidney disease $(183,184)$. This suggests that although each receptor can enhance EF responses, only TLR-7 induces the production of pathogenic antibodies, or permits the inflammatory response needed to cause disease.

Besides a B cell-intrinsic role of TLR signaling, B cell extrinsic TLR signaling can also enhance T-B interactions through the increased activation of DCs (185). Enhanced T-B interactions in this situation have the potential to enhance T-dependent PC differentiation in both EF and GC pathways. B cells as well as myeloid cells from SLE patients have increased expression of TLRs, and SLE patients may have increased proinflammatory responses to TLR ligands (186), which can contribute to stronger T-independent and T-dependent EF responses.

\section{B Cell Hyperresponsiveness}

A well-known feature of SLE is B cell hyperresponsiveness, which causes increased signaling upon BCR ligation by antigen $(187,188)$. The increased signaling can derive from increased activity of signaling molecules in the BCR pathway (many of which are genetic risk factors for SLE; discussed below) (189), or through a synergy between BCR triggering and other signaling pathways, such as TLR, BAFF, and type I IFN, which can each lower the threshold for B cell activation through the BCR and contribute to the activation of B cells $(59,190,191)$. Type I IFN is necessary for a complete response after BCR/TLR7 stimulation, and increments in type I IFN can overcome tolerance that normally occurs after repetitive stimulation of TLRs (192). The fact that high affinity $\mathrm{B}$ cells are more prone to expansion at the EF PB stage $(75,76)$ suggests that the increased BCR signaling that occurs in SLE may preferentially stimulate EF responses.

\section{Increased CSR}

Increased CSR in EF responses is another feature of SLE that may contribute to enhanced pathogenicity of EF PCs, in particular if the balance between protective IgM and pathogenic IgG is altered. Increased CSR has been described both in lupus-prone mouse models as well as SLE patients (193). In particular, a special subset of EF T cells in the MRL/lpr mice has been described to contribute to the expansion of class switched IgG + EF PCs. These EF T cells are dependent on Bcl-6, Stat3, and ICOS, and they mediate IgG CSR through CD40-CD40L interactions and IL-21 (167, 168). A similar subset of $\mathrm{T}$ cells has been described in EF responses in 
non-autoimmune mice, although there they localized at the T-B border, and it is not clear if they migrate to EF foci as well (80). EF Th cells express CXCR4, as opposed to Tfh cells which express CXCR5 (or both) $(194,195)$. While the EF Th cell subset is present in MRL/lpr mice which have a dominant EF phenotype, mice with a more pronounced GC pathway, such as NZB/W, have a more mixed T cell phenotype (168). IgG CSR in MRL/lpr mice, as well as in graft versus host-mediated autoimmunity, is almost completely dependent on ICOS, as ICOS-deficiency leads to lower expression of CXCR4, as well as diminished secretion of IL-21 $(167,168)$. T-independent factors can also increase EF CSR in SLE. In AM14 rheumatoid factor transgenic MRL/lpr mice, T cells are required for the spontaneous production of rheumatoid factor, but not when $\mathrm{B}$ cells are exposed to chromatin immune complexes which will trigger both the BCR and TLR (196).

Increased CSR has been described in circulating PBs of SLE patients, and at least some of these have low mutation rates, suggestive of an EF origin (125). However, all EF-derived PBs need not have low mutation rates. Factors that increase CSR in EF PCs in mice, such as IL-21, are increased in SLE patients (197), and factors that mediate T-independent CSR, such as TLR signaling and the myeloid-derived cytokine BAFF, are also increased in SLE (198). It is therefore conceivable that SLE patients can exhibit increased CSR in EF responses.

\section{Increased SHM}

Besides the increased CSR in EF PCs in MRL/lpr mice, SHM has also been shown to occur in EF foci, probably under the influence of EF Th cells. However, SHM can also occur in response to chromatin immune complexes in a T-independent manner $(166,168,196,199)$. This SHM potentially leads to affinity maturation (although probably to a lesser extent than in the GC) in autoreactive EF PCs, but no mechanism has been described for antigen selection and affinity maturation in EF responses.

\section{GC Responses in SLE}

Germinal center responses are well known to be increased in lupus-prone mice, and SLE patients have increased numbers of circulating pre-GC B cells, switched memory B cells and Tfh cells, suggestive of enhanced GC responses $(169,200,201)$. Given that IgG anti-DNA autoantibodies which are considered to be pathogenic in SLE show evidence of SHM (202), the production of autoreactive PCs by SHM of nonautoreactive naive B cells within the GC has been considered an important contributor to the development of SLE in both mice (203) and humans (204). The following mechanisms can contribute to GC-derived autoreactive PCs (Figure 5).

\section{Loss of FO Exclusion}

In normal conditions, autoreactive naive B cells undergo anergy that leads to FO exclusion and prevents their recruitment into GC responses. However, in SLE, these B cells are able to enter the GC, and continue their differentiation into PCs $(155,205)$.

\section{B Cell Hyperresponsiveness}

As discussed above, $\mathrm{B}$ cell hyperresponsiveness can enhance EF responses and may also potentiate GC responses (206). Hyperresponsiveness could lead to increased positive selection

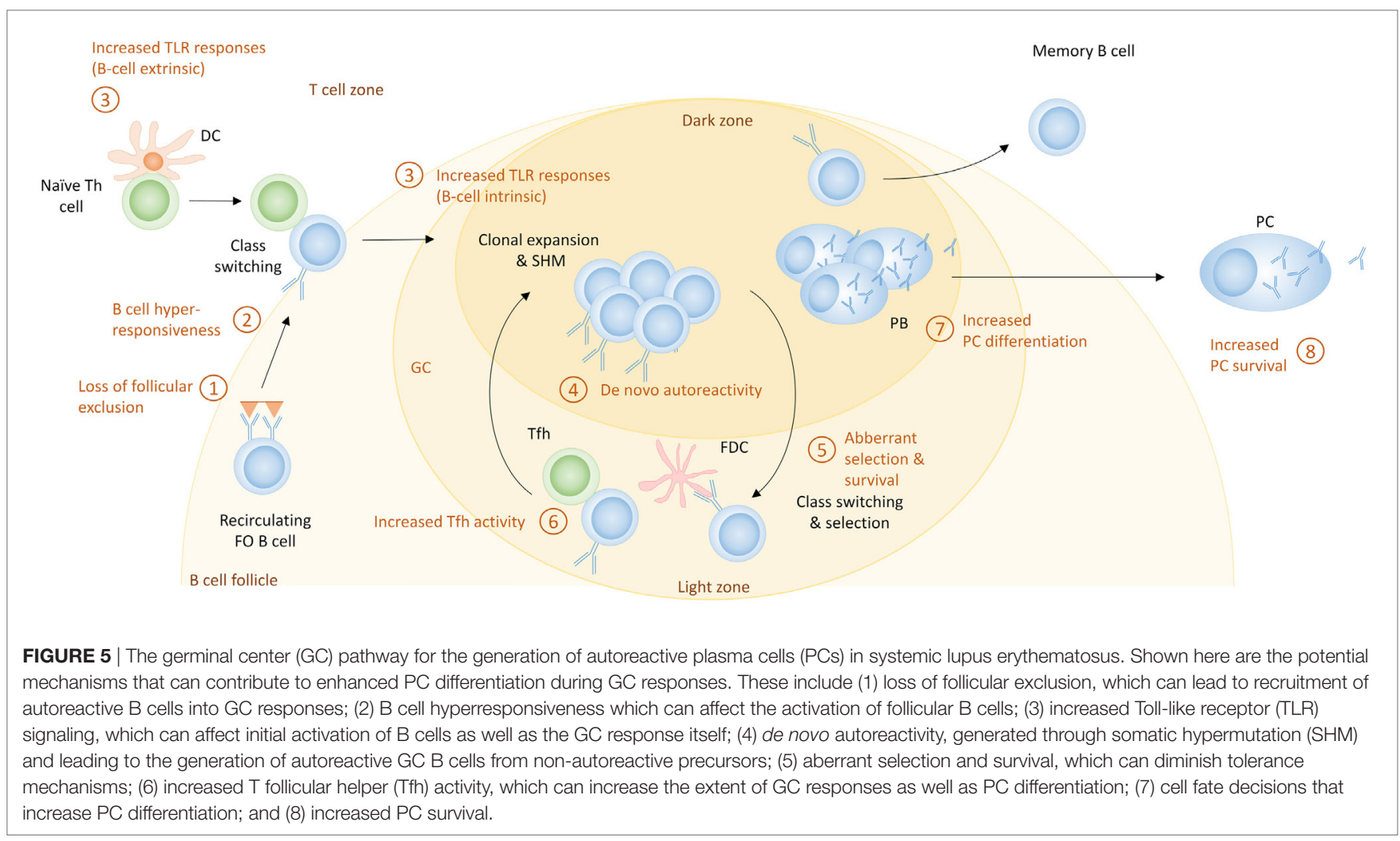


in the light zone and subsequent proliferation in the dark zone, thereby amplifying GC responses (207).

\section{Increased TLR Responses}

Toll-like receptors, which are involved in the EF pathway, also have a role in the GC response. Loss of MyD88 causes a loss of $\mathrm{GC}$ formation; interestingly, this alteration may be attributed to the function of TLR-7 and not TLR-9 $(208,209)$. Increased function of TLR-7 causes an increment in spontaneous GC formation and an autoimmunity phenotype (208). B cell-intrinsic MyD88 signaling specifically enhances GC responses when antigen and TLR ligand are coupled; self-antigen that can trigger both TLRs and the BCR will presumably have the same ability. It was recently demonstrated that FDCs, which are crucial for the maintenance of GCs and FO architecture, express type I IFN through a TLR-7 pathway upon internalizing complement-opsonized self-immune complexes through the complement receptor CD21 in the 564Igi RNP-specific lupus mouse model; this pathway is important for spontaneous GC formation and production of isotype-switched autoantibodies (210). 564Igi BM chimeras in which the recipient FDCs were TLR-7-deficient exhibited less autoimmunity. As many SLE antigens can activate TLRs $(1,190,191)$, these represent potent pathways to amplify GC responses.

\section{De Novo Autoreactivity}

Although loss of FO exclusion can lead to recruitment of autoreactive naive cells into GC reactions, SHM of nonautoreactive B cells can lead to de novo autoreactivity in GC B cells $(202,211)$. Whether these cells are able to differentiate into PCs has not been reported, but most pathogenic antibodies in SLE show signs of SHM, and de novo autoreactivity explains a large fraction of the autoreactive IgG + memory cells in SLE patients $(204,212)$. These studies suggest that GC B cells retain autoreactivity generated through SHM.

\section{Aberrant Selection and Survival of GC B Cells}

Another mechanism for the generation of autoreactive PCs in the GC is increased survival of GC B cells. It has been shown that SLE patients have increased levels of BAFF (213). While BAFF has a large role in the EF pathway of differentiation of PCs, it also expands the Tfh cell population and promotes formation of GC and survival of B cells. This could be a contributing factor in allowing the breach of B cell tolerance seen in SLE patients $(214,215)$. As a result of increased BAFF, naive B cells with moderate affinity that would normally undergo apoptosis, may be rescued and enter a GC response.

\section{Increased Tfh Activity}

Another mechanism that leads to the development of autoreactive PCs in the GC is increased Tfh activity (216). One cytokine important for the development of autoreactive PCs is IL-21, a cytokine produced by Tfh cells (72). The number of Tfh cells as well as the level of IL- 21 has been shown to be increased in lupusprone mice and SLE patients $(217,218)$. IL-21 increases IgG PC number $(72,217)$, and Tfh cells can alter selection and allow the differentiation of autoreactive B cells into autoreactive antibody secreting PCs (219). In lupus-prone mice, OX40L expression by $\mathrm{B}$ cells contributes to the autoimmune phenotype, presumably through its effect on Tfh cells $(90,220)$.

\section{Increased PC Differentiation}

$\mathrm{B}$ cell hyperresponsiveness may also increase the generation of PCs in SLE by directing more B cells to undergo PC differentiation. SLE patients often have increased numbers of circulating PBs; in one study this inversely correlates with the number of CD27 + memory cells, suggesting a preferred differentiation pathway (221). Lupus-prone mice, including the ones that have a GC phenotype, have vast increases in their PC numbers, which exceeds the expansion of the memory compartment. This suggests that there may be preferential output of PCs from the GC in SLE.

\section{Increased Survival of PCs}

Another possible mechanism for increased autoantibody titers is increased survival of PCs (Figures 2 and 3), which might occur if excess survival factors are present. Increased expression of the cytokines BAFF, APRIL, and IL-6 is present in lupus-prone mice (222, 223), suggesting that these cytokines can support enhanced PC survival. Although in healthy mice a limited number of PCs can survive in BM and spleen, these organs in lupus-prone mice gain additional capacity and exhibit an increased number of PCs (224). Both lupus-prone mice and SLE patients often exhibit hypergammaglobulinemia $(225,226)$, which may also be caused by an increased capacity to support PC survival in SLE patients. As both EF and GC-derived PCs can either stay in the spleen or stay in the lymph nodes or migrate to the BM, these factors will probably affect both types of PCs. In addition, several lupusprone mouse strains have increased levels of CXCL12 in their inflamed kidneys, which may allow recruitment of PCs to this organ (226-228).

\section{GENETIC RISK ALLELES}

Whereas both EF and GC pathways can lead to autoantibody production, we propose that genetic factors may cause a dominance of either of these pathways in individual patients. Approximately one hundred risk loci have been associated with SLE, and genes within these loci have been broadly cast into categories involving DNA degradation and clearance of apoptotic/cellular debris, innate immunity, including TLR and IFN signaling, and adaptive immunity (229). Some overlap or fall outside these categories, and others are undefined. Most variants are in non-coding regions that may alter expression levels that can determine the magnitude of a response in a celllineage and stage-specific manner. Several risk genes have been described to alter $\mathrm{B}$ cell selection, activation, differentiation and/or survival in a B cell-intrinsic fashion, including LYN, BLK, BANK1, PTPN22, TNFAIP3, TNIP1, CSK, and FCGR2B $(189,230)$. Although it is known that these risk alleles alter $\mathrm{B}$ cell signaling, their effect on PC differentiation has not been 
TABLE 1 | The role of genes with risk alleles in EF and GC responses.

\begin{tabular}{|c|c|c|c|c|c|}
\hline Gene & Function of gene & Function of risk allele & Potential role in EF & Potential role in GC & Reference \\
\hline HLA class I/ genes & Antigen presentation & $\begin{array}{l}\text { Presentation of self-specific T cell } \\
\text { epitopes }\end{array}$ & $\begin{array}{l}\text { May increase T-dependent } \\
\text { EF responses }\end{array}$ & $\begin{array}{l}\text { Expansion of Tfh, GC responses and } \\
\text { PC differentiation }\end{array}$ & $(103,231,232)$ \\
\hline TNFS4 (OX4OL) & $\begin{array}{l}\text { Costimulatory molecule on many } \\
\text { cell types primarily interacting with } \\
\text { OX40 on activated T cells promoting } \\
\text { T cell functions, cytokine and Ab } \\
\text { production, and PC generation }\end{array}$ & $\begin{array}{l}\text { Most likely a response eQTL, as DNA } \\
\text { heterozygous for the 5' rs2205860 } \\
\text { SNP had enhanced binding to NF-kB; } \\
\text { no significant differences in basal } \\
\text { expression in EBV-transformed cells } \\
\text { or primary cells }\end{array}$ & $\begin{array}{l}\text { Required for T cell-dependent } \\
\text { EF Ab response driven } \\
\text { by MZ DCs }\end{array}$ & $\begin{array}{l}\text { Supports Tfh maturation in mice } \\
\text { (B cell-intrinsic) and in humans } \\
\text { (expression on myeloid APCs) }\end{array}$ & $\begin{array}{l}(64,90,220 \\
233,234)\end{array}$ \\
\hline$C D 80$ & $\begin{array}{l}\text { T cell costimulation through CD28, } \\
\text { CTLA-4, PD-L1 }\end{array}$ & Unknown & $\begin{array}{l}\text { Little effect on Ab production } \\
\text { by short-lived plasmablasts } \\
\text { (in CD80-/- mice) }\end{array}$ & $\begin{array}{l}\text { Increased maturation of Tfh and } \\
\text { generation of long-lived PC }\end{array}$ & (91) \\
\hline LYN & $\begin{array}{l}\text { Src-family kinase that phosphorylates } \\
\text { both activating and inhibitory receptors } \\
\text { in B cells and myeloid cells. Its role in } \\
\text { activating ITAMs is probably redundant } \\
\text { with other Src family kinases, therefore } \\
\text { its role in inhibitory receptors seems } \\
\text { most crucial }\end{array}$ & $\begin{array}{l}\text { Unknown SLE patients have } \\
\text { decreased expression of Lyn } \\
\text { in B cells }\end{array}$ & $\begin{array}{l}\text { Lyn-/- mice have EF PC } \\
\text { differentiation without GCs } \\
\text { in some studies }\end{array}$ & $\begin{array}{l}\text { Lyn-/- mice have spontaneous } \\
\text { GCs in some studies }\end{array}$ & $(187,235,236)$ \\
\hline$B L K$ & $\begin{array}{l}\text { Src-family kinase that phosphorylates } \\
\text { both activating and inhibitory receptors } \\
\text { in B cells }\end{array}$ & $\begin{array}{l}\text { Decreased expression in B cells, } \\
\text { increased B cell activation }\end{array}$ & $\begin{array}{l}\text { Increased TI IgG antibody } \\
\text { responses in Blk+/- mice, } \\
\text { with no effect on IgM }\end{array}$ & $\begin{array}{l}\text { Increased numbers of switched memory } \\
\text { cells in risk carriers suggests more active } \\
\text { GC responses, but TD antibody responses } \\
\text { in Blk+/- or }-/- \text { mice not affected }\end{array}$ & $(237-240)$ \\
\hline BANK1 & $\begin{array}{l}\text { Signaling molecule involved in BCR- } \\
\text { and } C D 40 \text {-mediated signaling in } \mathrm{B} \text { cells, } \\
\text { positively regulates } \mathrm{Ca}^{2+} \text { release in } \mathrm{B} \text { cells, } \\
\text { negatively regulates } \mathrm{CD} 40 \text {-mediated } \\
\text { signaling }\end{array}$ & $\begin{array}{l}\text { Differential expression of two splice } \\
\text { variants, but functional consequences } \\
\text { unknown }\end{array}$ & $\begin{array}{l}\text { Normal antibody responses } \\
\text { to TI antigen, but the IgM } \\
\text { response in TD responses } \\
\text { was increased, possibly due } \\
\text { to increased survival of EF PCs }\end{array}$ & $\begin{array}{l}\text { Normal IgG antibody responses to TD } \\
\text { antigen suggesting that there is no major } \\
\text { influence on switched TD responses, } \\
\text { although there is a slight increase in } \\
\text { spontaneous IgG2a in } \\
\text { Bank1-/- mice }\end{array}$ & $(241-243)$ \\
\hline PTPN22 (Lyp) & $\begin{array}{l}\text { Protein tyrosine phosphatase that } \\
\text { has inhibitory function in B and T cell } \\
\text { signaling }\end{array}$ & $\begin{array}{l}\text { Risk allele has increased inhibitory } \\
\text { function, causing decreased B cell } \\
\text { activation, proliferation and signaling } \\
\text { leading to impaired central B cell } \\
\text { tolerance as well as impaired T cell } \\
\text { responses }\end{array}$ & $\begin{array}{l}\text { Impaired central tolerance; unclear } \\
\text { if PTPN22 affects EF responses; } \\
\text { deficiency of PEP (mouse ortholog) } \\
\text { in mice did not alter spontaneous } \\
\text { IgM and lgG3 levels, suggesting } \\
\text { no effect on extrafollicular antibody } \\
\text { production }\end{array}$ & $\begin{array}{l}\text { Lower frequency of memory cells in risk allele } \\
\text { carriers suggests that it may inhibit GC } \\
\text { responses consistent with increased GCs } \\
\text { and serum IgG in PEP-/- mice }\end{array}$ & $(206,244-247)$ \\
\hline TNFAIP3 (A20) & $\begin{array}{l}\text { Negative regulator of NF-kB signaling } \\
\text { in response to TLR, TNF, and CD } 40 \\
\text { signaling in } \mathrm{B} \text { cells and other immune } \\
\text { cells }\end{array}$ & $\begin{array}{l}\text { Reduced expression in EBV } \\
\text { transformed cells with one risk variant } \\
\text { and reduced anti-inflammatory activity } \\
\text { in transfected HEK cells with another } \\
\text { risk variant }\end{array}$ & $\begin{array}{l}\text { B cell-specific A20 deficiency in } \\
\text { mice leads to alterations in the MZ } \\
\text { compartment and consistently } \\
\text { enhanced lgM production } \\
\text { (spontaneous, as well as } \\
\text { TD and TI immunizations), } \\
\text { but no difference in lgG3 }\end{array}$ & $\begin{array}{l}\text { B cell specific A20 deficiency in mice leads } \\
\text { to elevated numbers of GC B cells, and } \\
\text { spontaneous IgG2 levels in old mice which } \\
\text { deposited in kidneys; however, inconsistent } \\
\text { effects on TD IgG production upon } \\
\text { immunization in different studies }\end{array}$ & (248-253) \\
\hline
\end{tabular}


TABLE 1 | Continued

\begin{tabular}{|c|c|c|c|c|c|}
\hline Gene & Function of gene & Function of risk allele & Potential role in EF & Potential role in GC & Reference \\
\hline TNIP1 & $\begin{array}{l}\text { Ubiquitin-binding protein with diverse } \\
\text { targets; interaction with TNFAIP3 } \\
\text { negatively regulates NF-kB; also known } \\
\text { to repress PPARs, which may increase } \\
\text { B cell activity }\end{array}$ & $\begin{array}{l}\text { Reduced expression in EBV- } \\
\text { transformed B cells from } \mathrm{H} 1 \text { and } \mathrm{H} 2 \\
\text { risk haplotypes; } \mathrm{H} 1 \text { contains coding } \\
\text { SNP near a nuclear export sequence }\end{array}$ & $\begin{array}{l}\text { Mutation of polyubiquitin binding } \\
\text { site increased formation } \\
\text { of EF PCs }\end{array}$ & $\begin{array}{l}\text { Mutation of polyubiquitin-binding site } \\
\text { induced spontaneous GC, increased TFH, } \\
\text { CSR, and production of autoreactive Abs } \\
\text { thru TLR-mediated NF-kB pathway }\end{array}$ & $(254,255)$ \\
\hline CSK & $\begin{array}{l}\text { Tyrosine kinase protein that } \\
\text { phosphorylates } \\
\text { Src family kinases leading to their } \\
\text { inactivation. Src family kinases can act on } \\
\text { both activating and inhibitory receptors in } \\
\text { B and T cells }\end{array}$ & $\begin{array}{l}\text { Increased expression in B cells, } \\
\text { increased B cell activation (Lyn } \\
\text { phosphorylation, } \mathrm{Ca}^{2+} \text { mobilization), } \\
\text { expansion of transitional B cells }\end{array}$ & $\begin{array}{l}\text { Unknown, but increased signaling } \\
\text { may enhance PC differentiation }\end{array}$ & $\begin{array}{l}\text { Csk is low in memory cells but its function } \\
\text { in GC responses is not known }\end{array}$ & (256) \\
\hline FCGR2B & $\begin{array}{l}\text { Inhibitory receptor for lgG on B cells } \\
\text { and other immune cells }\end{array}$ & $\begin{array}{l}\text { Impairment of receptor mobility, lipid } \\
\text { rafts and inhibitory signaling }\end{array}$ & $\begin{array}{l}\text { Enhanced antibody production } \\
\text { upon Tl immunization, although } \\
\text { not observed in all studies }\end{array}$ & $\begin{array}{l}\text { Enhanced GC responses in FCGR2B-/- } \\
\text { mice. Spontaneous GC B cells have } \\
\text { increased self-reactivity, but the checkpoint } \\
\text { to PCs is still intact in FCGR2B-/- mice, so } \\
\text { uncertain if autoreactive PCs in these mice } \\
\text { are GC-derived }\end{array}$ & $(150,257-262)$ \\
\hline IRF5 & $\begin{array}{l}\text { Production of type I IFN in response to } \\
\text { TLR ligands, macrophage polarization, } \\
\text { enhanced PC differentiation }\end{array}$ & $\begin{array}{l}\text { Increased expression and activation } \\
\text { in monocytes from SLE patients with } \\
\text { the risk allele }\end{array}$ & $\begin{array}{l}\text { IRF5-/- mice have decreased IgG1 } \\
\text { responses upon TI immunization } \\
\text { and have decreased PC numbers } \\
\text { in MRL/lpr mice, suggesting that } \\
\text { increased expression of IRF5 may } \\
\text { enhance EF responses }\end{array}$ & $\begin{array}{l}\text { IRF5-/- mice have diminished GC-derived } \\
\text { antibodies, suggesting the IRF5 risk allele } \\
\text { may enhance GC PC differentiation }\end{array}$ & $(263-267)$ \\
\hline STAT4 & $\begin{array}{l}\text { Transcription factor critical for myeloid } \\
\text { and lymphocyte functions; major } \\
\text { responder to IL-12; role in IFN- } \alpha \text { signaling }\end{array}$ & $\begin{array}{l}\text { Increased expression in PBMCs } \\
\text { correlated with SNPs rs } 3821236 \text {, } \\
\text { rs3024866 (both in the same } \\
\text { haplotype block) and rs7574865 } \\
\text { but not with other SNPs }\end{array}$ & $\begin{array}{l}\text { STAT4-/- had no effect on } \\
\text { antibody titers or pathology in EF } \\
\text { model (MRL/lpr) }\end{array}$ & $\begin{array}{l}\text { Regulates Tfh through Bcl-6 and T-bet } \\
\text { in T cells; indirectly upregulates T-bet in } \\
\text { B cells, which facilitates spontaneous GC; } \\
\text { STAT4-/- reduced autoantibody production } \\
\text { and glomerulonephritis in B6.TC model } \\
\text { (Sle1,2,3 congenic) }\end{array}$ & (268-270) \\
\hline $\mathrm{BACH} 2$ & $\begin{array}{l}\text { Transcriptional repressor that promotes } \\
\mathrm{CSR} / \mathrm{SHM} \text { and is required for memory } \\
\mathrm{B} \text { cell differentiation }\end{array}$ & $\begin{array}{l}\text { No expression differences associated } \\
\text { with rs597325 in primary blood cell } \\
\text { types }\end{array}$ & $\begin{array}{l}\text { Deficiency increases IgM PC } \\
\text { differentiation in vitro }\end{array}$ & $\begin{array}{l}\text { Bach2 can enhance memory B cell } \\
\text { differentiation while blocking plasma cell } \\
\text { differentiation }\end{array}$ & $(105,271-273)$ \\
\hline PRDM1 (Blimp-1) & $\begin{array}{l}\text { Transcription factor required for PC } \\
\text { differentiation/transcription factor that } \\
\text { alters DC function }\end{array}$ & $\begin{array}{l}\text { Decreased expression of Blimp-1 in } \\
\text { DCs leading to increased cytokine } \\
\text { production (unknown function of risk } \\
\text { allele in PCs) }\end{array}$ & Unknown & $\begin{array}{l}\text { Expansion of Th and increased GC } \\
\text { responses in DC-Blimp-1-deficient mice }\end{array}$ & $(274,275)$ \\
\hline IRF8 & $\begin{array}{l}\text { Transcription factor that inhibits PC } \\
\text { differentiation together with PU.1 and } \\
\text { distribution into FO or MZ compartments }\end{array}$ & $\begin{array}{l}\text { Increased expression in EBV- } \\
\text { transformed cells }\end{array}$ & $\begin{array}{l}\text { Increased IRF8 expression } \\
\text { presumably would decrease } \\
\text { PC differentiation }\end{array}$ & $\begin{array}{l}\text { Increased function of IRF8 could lead to } \\
\text { enhanced GC responses, through regulation } \\
\text { of Bcl-6, AID, and MDM2 }\end{array}$ & (276-278) \\
\hline IKZF3 (Aiolos) & $\begin{array}{l}\text { Transcription factor involved in } \\
\text { lymphocyte development and function; } \\
\text { important in B cell maturation and } \\
\text { activation }\end{array}$ & Unknown & $\begin{array}{l}\text { Deficiency impairs the MZ B cell } \\
\text { compartment but not the generation } \\
\text { of short-lived PCs following } \\
\text { immunization }\end{array}$ & $\begin{array}{l}\text { Deficiency induces spontaneous GCs and } \\
\text { production of autoantibodies; deficiency } \\
\text { prevents generation of high-affinity BM } \\
\text { PCs following immunization }\end{array}$ & (279-281) \\
\hline
\end{tabular}




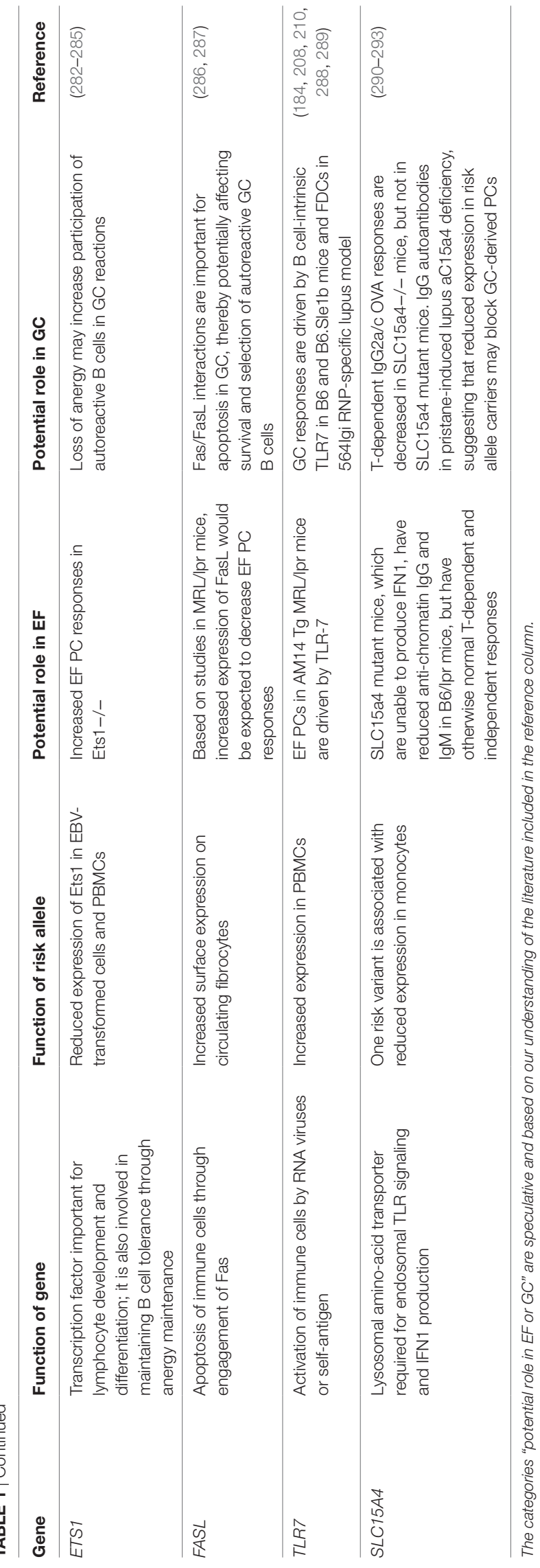

extensively investigated, and most of our understanding of the role of these genes in $\mathrm{EF}$ and $\mathrm{GC}$ responses derives from mouse models. Other risk alleles are involved in $\mathrm{B}-\mathrm{T}$ cell interactions, memory or PC differentiation, and IFN/TLR signaling. For many of these, the functional consequence of the risk allele has not been determined. However, it is reasonable to ask whether these risk alleles may alter $\mathrm{EF}$ or GC responses.

Table 1 shows risk alleles that can alter B cell responses and subsequently PC differentiation. These risk alleles can function in a B cell-intrinsic or -extrinsic manner. We propose that some risk alleles, such as TLR7, FAS, IRF5, TNFAIP3, and TNIP1, can modify both EF and GC responses.

Certain risk alleles, such as HLA class II genes, FCGR2B, STAT4, CD80, IRF8, and PRDM1, most likely drive GC responses, whereas other risk alleles, such as ETS1, LYN, BACH2, and BLK, may preferentially drive EF responses in SLE, although this pathway has not been extensively explored. Further understanding of the exact role of each risk allele in plasma cell differentiation pathways may enhance our insight into patient heterogeneity.

\section{CONCLUSION}

In this review, we have described the PC differentiation pathways which can contribute to the development of autoantibody production in SLE. Whereas both EF and GC pathways may be active in the same patient, we propose that certain genetic risk alleles contribute to the dominance of one of these pathways. The dominant PC differentiation pathway, determined by the composite of risk alleles, may contribute to patient heterogeneity and to response to therapy. Although it is likely that different therapeutics alter each pathway to a different extent, there is to our knowledge not enough understanding of the molecular pathways in each response nor is there clear evidence which therapeutics target which pathway. These pathways are not as distinct as we thought, nor can the pathway taken by a PC be easily distinguished with current knowledge. A more thorough analysis of these pathways, their role in SLE, and the contribution of genetic risk alleles to each pathway may provide us with distinct targets to allow precision therapy.

\section{AUTHOR CONTRIBUTIONS}

$\mathrm{SM}, \mathrm{AB}$, and YA-F contributed to writing the manuscript. JS and $\mathrm{BD}$ contributed to the concept, reviewing, and writing of the manuscript.

\section{FUNDING}

JS received financial support from American Autoimmune Related Disease Association. This work was further supported by NIH 1P01 AI073693 and Lupus Research Institute. 


\section{REFERENCES}

1. Suurmond J, Diamond B. Autoantibodies in systemic autoimmune diseases: specificity and pathogenicity. J Clin Invest (2015) 125(6):2194-202. doi:10.1172/JCI78084

2. Tan EM, Cohen AS, Fries JF, Masi AT, McShane DJ, Rothfield NF, et al. The 1982 revised criteria for the classification of systemic lupus erythematosus. Arthritis Rheum (1982) 25(11):1271-7. doi:10.1002/art.1780251101

3. Vas J, Gronwall C, Marshak-Rothstein A, Silverman GJ. Natural antibody to apoptotic cell membranes inhibits the proinflammatory properties of lupus autoantibody immune complexes. Arthritis Rheum (2012) 64(10):3388-98. doi:10.1002/art.34537

4. Li QZ, Xie C, Wu T, Mackay M, Aranow C, Putterman C, et al. Identification of autoantibody clusters that best predict lupus disease activity using glomerular proteome arrays. J Clin Invest (2005) 115(12):3428-39. doi:10.1172/ JCI23587

5. Mannoor K, Matejuk A, Xu Y, Beardall M, Chen C. Expression of natural autoantibodies in MRL-lpr mice protects from lupus nephritis and improves survival. J Immunol (2012) 188(8):3628-38. doi:10.4049/jimmunol.1102859

6. Nemazee D, Buerki K. Clonal deletion of autoreactive B lymphocytes in bone marrow chimeras. Proc Natl Acad Sci U S A (1989) 86(20):8039-43. doi:10.1073/pnas.86.20.8039

7. Wardemann H, Yurasov S, Schaefer A, Young JW, Meffre E, Nussenzweig MC. Predominant autoantibody production by early human B cell precursors. Science (2003) 301(5638):1374-7. doi:10.1126/science.1086907

8. Pewzner-Jung Y, Friedmann D, Sonoda E, Jung S, Rajewsky K, Eilat D. B cell deletion, anergy, and receptor editing in "knock in" mice targeted with a germline-encoded or somatically mutated anti-DNA heavy chain. J Immunol (1998) 161(9):4634-45.

9. Mandik-Nayak L, Bui A, Noorchashm H, Eaton A, Erikson J. Regulation of anti-double-stranded DNA B cells in nonautoimmune mice: localization to the T-B interface of the splenic follicle. J Exp Med (1997) 186(8):1257-67. doi:10.1084/jem.186.8.1257

10. Pugh-Bernard AE, Silverman GJ, Cappione AJ, Villano ME, Ryan DH, Insel RA, et al. Regulation of inherently autoreactive VH4-34 B cells in the maintenance of human B cell tolerance. J Clin Invest (2001) 108(7):1061-70. doi:10.1172/JCI12462

11. Nutt SL, Hodgkin PD, Tarlinton DM, Corcoran LM. The generation of antibody-secreting plasma cells. Nat Rev Immunol (2015) 15(3):160-71. doi:10.1038/ nri3795

12. Chernova I, Jones DD, Wilmore JR, Bortnick A, Yucel M, Hershberg U, et al. Lasting antibody responses are mediated by a combination of newly formed and established bone marrow plasma cells drawn from clonally distinct precursors. J Immunol (2014) 193(10):4971-9. doi:10.4049/jimmunol.1401264

13. Sanz I, Wei C, Lee FE, Anolik J. Phenotypic and functional heterogeneity of human memory B cells. Semin Immunol (2008) 20(1):67-82. doi:10.1016/ j.smim.2007.12.006

14. Kallies A, Hasbold J, Tarlinton DM, Dietrich W, Corcoran LM, Hodgkin PD, et al. Plasma cell ontogeny defined by quantitative changes in blimp-1 expression. J Exp Med (2004) 200(8):967-77. doi:10.1084/jem.20040973

15. Jeurissen A, Ceuppens JL, Bossuyt X. T lymphocyte dependence of the antibody response to 'T lymphocyte independent type 2' antigens. Immunology (2004) 111(1):1-7. doi:10.1111/j.1365-2567.2004.01775.x

16. Shih TA, Roederer M, Nussenzweig MC. Role of antigen receptor affinity in T cell-independent antibody responses in vivo. Nat Immunol (2002) 3(4): 399-406. doi:10.1038/ni776

17. Lentz VM, Manser T. Cutting edge: germinal centers can be induced in the absence of T cells. J Immunol (2001) 167(1):15-20. doi:10.4049/ jimmunol.167.1.15

18. Mongini PK, Stein KE, Paul WE. T cell regulation of IgG subclass antibody production in response to T-independent antigens. JExp Med (1981) 153(1):1-12. doi:10.1084/jem.153.1.1

19. Vinuesa CG, Chang PP. Innate B cell helpers reveal novel types of antibody responses. Nat Immunol (2013) 14(2):119-26. doi:10.1038/ni.2511

20. Khan AQ, Chen Q, Wu ZQ, Paton JC, Snapper CM. Both innate immunity and type 1 humoral immunity to Streptococcus pneumoniae are mediated by MyD88 but differ in their relative levels of dependence on toll-like receptor 2. Infect Immun (2005) 73(1):298-307. doi:10.1128/IAI.73.1.298-307.2005
21. Hou B, Saudan P, Ott G, Wheeler ML, Ji M, Kuzmich L, et al. Selective utilization of toll-like receptor and MyD88 signaling in B cells for enhancement of the antiviral germinal center response. Immunity (2011) 34(3):375-84 doi:10.1016/j.immuni.2011.01.011

22. Guay HM, Andreyeva TA, Garcea RL, Welsh RM, Szomolanyi-Tsuda E. MyD88 is required for the formation of long-term humoral immunity to virus infection. J Immunol (2007) 178(8):5124-31. doi:10.4049/jimmunol.178. 8.5124

23. Raval FM, Mishra R, Garcea RL, Welsh RM, Szomolanyi-Tsuda E. Long-lasting $\mathrm{T}$ cell-independent IgG responses require MyD88-mediated pathways and are maintained by high levels of virus persistence. MBio (2013) 4(6):e812-3. doi:10.1128/mBio.00812-13

24. Leadbetter EA, Rifkin IR, Hohlbaum AM, Beaudette BC, Shlomchik MJ, Marshak-Rothstein A. Chromatin-IgG complexes activate B cells by dual engagement of IgM and toll-like receptors. Nature (2002) 416(6881):603-7. doi: $10.1038 / 416603 \mathrm{a}$

25. Jego G, Palucka AK, Blanck JP, Chalouni C, Pascual V, Banchereau J. Plasmacytoid dendritic cells induce plasma cell differentiation through type I interferon and interleukin 6. Immunity (2003) 19(2):225-34. doi:10.1016/ S1074-7613(03)00208-5

26. Litinskiy MB, Nardelli B, Hilbert DM, He B, Schaffer A, Casali P, et al. DCs induce CD40-independent immunoglobulin class switching through BLyS and APRIL. Nat Immunol (2002) 3(9):822-9. doi:10.1038/ni829

27. Moore PA, Belvedere O, Orr A, Pieri K, LaFleur DW, Feng P, et al. BLyS: member of the tumor necrosis factor family and B lymphocyte stimulator. Science (1999) 285(5425):260-3. doi:10.1126/science.285.5425.260

28. He B, Santamaria R, Xu W, Cols M, Chen K, Puga I, et al. The transmembrane activator TACI triggers immunoglobulin class switching by activating B cells through the adaptor MyD88. Nat Immunol (2010) 11(9):836-45. doi:10.1038/ ni. 1914

29. Stavnezer J, Guikema JE, Schrader CE. Mechanism and regulation of class switch recombination. Annu Rev Immunol (2008) 26:261-92. doi:10.1146/ annurev.immunol.26.021607.090248

30. Rothaeusler K, Baumgarth N. B-cell fate decisions following influenza virus infection. Eur J Immunol (2010) 40(2):366-77. doi:10.1002/eji.200939798

31. Puga I, Cols M, Barra CM, He B, Cassis L, Gentile M, et al. B cell-helper neutrophils stimulate the diversification and production of immunoglobulin in the marginal zone of the spleen. Nat Immunol (2011) 13(2):170-80. doi:10.1038/ni.2194

32. Pone EJ, Zhang J, Mai T, White CA, Li G, Sakakura JK, et al. BCR-signalling synergizes with TLR-signalling for induction of AID and immunoglobulin class-switching through the non-canonical NF-kappaB pathway. Nat Commun (2012) 3:767. doi:10.1038/ncomms1769

33. Herzenberg LA, Stall AM, Lalor PA, Sidman C, Moore WA, Parks DR. The Ly-1 B cell lineage. Immunol Rev (1986) 93:81-102.

34. Hardy RR, Carmack CE, Li YS, Hayakawa K. Distinctive developmental origins and specificities of murine CD5+ B cells. Immunol Rev (1994) 137:91-118.

35. Baumgarth $\mathrm{N}$. The double life of a B-1 cell: self-reactivity selects for protective effector functions. Nat Rev Immunol (2011) 11(1):34-46. doi:10.1038/nri2901

36. Hardy RR, Hayakawa K. CD5 B cells, a fetal B cell lineage. Adv Immunol (1994) 55:297-339.

37. Kasaian MT, Casali P. Autoimmunity-prone B-1 (CD5 B) cells, natural antibodies and self recognition. Auto immunity (1993) 15(4):315-29. doi:10.3109/08916939309115755

38. Hayakawa K, Hardy RR, Honda M, Herzenberg LA, Steinberg AD. Ly-1 B cells: functionally distinct lymphocytes that secrete IgM autoantibodies. Proc Natl Acad Sci U S A (1984) 81(8):2494-8. doi:10.1073/pnas.81.8.2494

39. Griffin DO, Holodick NE, Rothstein TL. Human B1 cells in umbilical cord and adult peripheral blood express the novel phenotype CD20+ CD27+ CD43+ CD70. J Exp Med (2011) 208(1):67-80. doi:10.1084/jem.20101499

40. Conger JD, Sage HJ, Corley RB. Correlation of antibody multireactivity with variable region primary structure among murine anti-erythrocyte autoantibodies. Eur J Immunol (1992) 22(3):783-90. doi:10.1002/eji.1830220323

41. Sindhava VJ, Bondada S. Multiple regulatory mechanisms control B-1 B cell activation. Front Immunol (2012) 3:372. doi:10.3389/fimmu.2012.00372

42. Cole LE, Yang Y, Elkins KL, Fernandez ET, Qureshi N, Shlomchik MJ, et al. Antigen-specific B-1a antibodies induced by Francisella tularensis LPS 
provide long-term protection against F. tularensis LVS challenge. Proc Natl Acad Sci U S A (2009) 106(11):4343-8. doi:10.1073/pnas.0813411106

43. Berland R, Wortis HH. Origins and functions of B-1 cells with notes on the role of CD5. Annu Rev Immunol (2002) 20:253-300. doi:10.1146/annurev. immunol.20.100301.064833

44. Haas KM, Poe JC, Steeber DA, Tedder TF. B-1a and B-1b cells exhibit distinct developmental requirements and have unique functional roles in innate and adaptive immunity to S. pneumoniae. Immunity (2005) 23(1):7-18. doi:10.1016/j.immuni.2005.04.011

45. Alugupalli KR, Leong JM, Woodland RT, Muramatsu M, Honjo T, Gerstein RM. B1b lymphocytes confer $\mathrm{T}$ cell-independent long-lasting immunity. Immunity (2004) 21(3):379-90. doi:10.1016/j.immuni.2004.06.019

46. Linton PJ, Lo D, Lai L, Thorbecke GJ, Klinman NR. Among naive precursor cell subpopulations only progenitors of memory B cells originate germinal centers. Eur J Immunol (1992) 22(5):1293-7.

47. Mantovani L, Wilder RL, Casali P. Human rheumatoid B-1a (CD5+ B) cells make somatically hypermutated high affinity IgM rheumatoid factors. J Immunol (1993) 151(1):473-88.

48. Murakami M, Yoshioka H, Shirai T, Tsubata T, Honjo T. Prevention of autoimmune symptoms in autoimmune-prone mice by elimination of B-1 cells. Int Immunol (1995) 7(5):877-82. doi:10.1093/intimm/7.5.877

49. Casali P, Notkins AL. Probing the human B-cell repertoire with EBV: polyreactive antibodies and CD5+ B lymphocytes. Annu Rev Immunol (1989) 7: 513-35. doi:10.1146/annurev.iy.07.040189.002501

50. Suzuki N, Sakane T, Engleman EG. Anti-DNA antibody production by CD5+ and CD5- B cells of patients with systemic lupus erythematosus. J Clin Invest (1990) 85(1):238-47.

51. Martin F, Oliver AM, Kearney JF. Marginal zone and B1 B cells unite in the early response against T-independent blood-borne particulate antigens. Immunity (2001) 14(5):617-29. doi:10.1016/S1074-7613(01)00129-7

52. Genestier L, Taillardet M, Mondiere P, Gheit H, Bella C, Defrance T. TLR agonists selectively promote terminal plasma cell differentiation of B cell subsets specialized in thymus-independent responses. J Immunol (2007) 178(12):7779-86. doi:10.4049/jimmunol.178.12.7779

53. Oliver AM, Martin F, Gartland GL, Carter RH, Kearney JF. Marginal zone B cells exhibit unique activation, proliferative and immunoglobulin secretory responses. Eur J Immunol (1997) 27(9):2366-74. doi:10.1002/eji.1830270935

54. Balazs M, Martin F, Zhou T, Kearney J. Blood dendritic cells interact with splenic marginal zone B cells to initiate T-independent immune responses. Immunity (2002) 17(3):341-52. doi:10.1016/S1074-7613(02)00389-8

55. Bialecki E, Paget C, Fontaine J, Capron M, Trottein F, Faveeuw C. Role of marginal zone B lymphocytes in invariant NKT cell activation. J Immunol (2009) 182(10):6105-13. doi:10.4049/jimmunol.0802273

56. van den Eertwegh AJ, Laman JD, Schellekens MM, Boersma WJ, Claassen E. Complement-mediated follicular localization of T-independent type-2 antigens: the role of marginal zone macrophages revisited. Eur J Immunol (1992) 22(3):719-26. doi:10.1002/eji.1830220315

57. Liu YJ, Zhang J, Lane PJ, Chan EY, MacLennan IC. Sites of specific B cell activation in primary and secondary responses to $\mathrm{T}$ cell-dependent and $\mathrm{T}$ cell-independent antigens. Eur JImmunol (1991) 21(12):2951-62. doi:10.1002/eji.1830211209

58. Pao LI, Lam KP, Henderson JM, Kutok JL, Alimzhanov M, Nitschke L, et al. B cell-specific deletion of protein-tyrosine phosphatase Shpl promotes B-1a cell development and causes systemic autoimmunity. Immunity (2007) 27(1):35-48. doi:10.1016/j.immuni.2007.04.016

59. Groom JR, Fletcher CA, Walters SN, Grey ST, Watt SV, Sweet MJ, et al. BAFF and MyD88 signals promote a lupuslike disease independent of T cells. J Exp Med (2007) 204(8):1959-71. doi:10.1084/jem.20062567

60. MacLennan IC, Toellner KM, Cunningham AF, Serre K, Sze DM, Zuniga E, et al. Extrafollicular antibody responses. Immunol Rev (2003) 194:8-18. doi:10.1034/j.1600-065X.2003.00058.x

61. Song H, Cerny J. Functional heterogeneity of marginal zone B cells revealed by their ability to generate both early antibody-forming cells and germinal centers with hypermutation and memory in response to a T-dependent antigen. J Exp Med (2003) 198(12):1923-35. doi:10.1084/jem.20031498

62. Oliver AM, Martin F, Kearney JF. IgMhighCD21high lymphocytes enriched in the splenic marginal zone generate effector cells more rapidly than the bulk of follicular B cells. J Immunol (1999) 162(12):7198-207.
63. Attanavanich K, Kearney JF. Marginal zone, but not follicular B cells, are potent activators of naive CD4 T cells. J Immunol (2004) 172(2):803-11. doi:10.4049/jimmunol.172.2.803

64. Chappell CP, Draves KE, Giltiay NV, Clark EA. Extrafollicular B cell activation by marginal zone dendritic cells drives $\mathrm{T}$ cell-dependent antibody responses. J Exp Med (2012) 209(10):1825-40. doi:10.1084/jem.20120774

65. Rubtsov A, Strauch P, Digiacomo A, Hu J, Pelanda R, Torres RM. Lsc regulates marginal-zone $\mathrm{B}$ cell migration and adhesion and is required for the IgM T-dependent antibody response. Immunity (2005) 23(5):527-38. doi:10.1016/j.immuni.2005.09.018

66. Cinamon G, Zachariah MA, Lam OM, Foss FW Jr, Cyster JG. Follicular shuttling of marginal zone B cells facilitates antigen transport. Nat Immunol (2008) 9(1):54-62. doi:10.1038/ni1542

67. Reif K, Ekland EH, Ohl L, Nakano H, Lipp M, Forster R, et al. Balanced responsiveness to chemoattractants from adjacent zones determines B-cell position. Nature (2002) 416(6876):94-9. doi:10.1038/416094a

68. Pereira JP, Kelly LM, Xu Y, Cyster JG. EBI2 mediates B cell segregation between the outer and centre follicle. Nature (2009) 460(7259):1122-6. doi:10.1038/nature08226

69. Toellner KM, Luther SA, Sze DM, Choy RK, Taylor DR, MacLennan IC, et al. Thelper 1 (Th1) and Th2 characteristics start to develop during $\mathrm{T}$ cell priming and are associated with an immediate ability to induce immunoglobulin class switching. J Exp Med (1998) 187(8):1193-204. doi:10.1084/jem. 187.8.1193

70. Rousset F, Garcia E, Defrance T, Peronne C, Vezzio N, Hsu DH, et al. Interleukin 10 is a potent growth and differentiation factor for activated human B lymphocytes. Proc Natl Acad Sci U S A (1992) 89(5):1890-3. doi:10.1073/pnas.89.5.1890

71. Lundgren M, Persson U, Larsson P, Magnusson C, Smith CI, Hammarstrom L, et al. Interleukin 4 induces synthesis of IgE and IgG4 in human B cells. Eur J Immunol (1989) 19(7):1311-5. doi:10.1002/eji.1830190724

72. Bryant VL, Ma CS, Avery DT, Li Y, Good KL, Corcoran LM, et al. Cytokinemediated regulation of human B cell differentiation into Ig-secreting cells: predominant role of IL-21 produced by CXCR5+ T follicular helper cells. J Immunol (2007) 179(12):8180-90. doi:10.4049/jimmunol.179.12.8180

73. Avery DT, Deenick EK, Ma CS, Suryani S, Simpson N, Chew GY, et al. B cell-intrinsic signaling through IL-21 receptor and STAT3 is required for establishing long-lived antibody responses in humans. J Exp Med (2010) 207(1):155-71. doi:10.1084/jem.20091706

74. Jacob J, Kelsoe G. In situ studies of the primary immune response to (4-hydroxy-3-nitrophenyl)acetyl. II. A common clonal origin for periarteriolar lymphoid sheath-associated foci and germinal centers. JExp Med (1992) 176(3):679-87. doi:10.1084/jem.176.3.679

75. Chan TD, Gatto D, Wood K, Camidge T, Basten A, Brink R. Antigen affinity controls rapid T-dependent antibody production by driving the expansion rather than the differentiation or extrafollicular migration of early plasmablasts. J Immunol (2009) 183(5):3139-49. doi:10.4049/jimmunol.0901690

76. Phan TG, Paus D, Chan TD, Turner ML, Nutt SL, Basten A, et al. High affinity germinal center B cells are actively selected into the plasma cell compartment. J Exp Med (2006) 203(11):2419-24. doi:10.1084/jem.20061254

77. Schwickert TA, Victora GD, Fooksman DR, Kamphorst AO, Mugnier MR, Gitlin AD, et al. A dynamic T cell-limited checkpoint regulates affinitydependent B cell entry into the germinal center. J Exp Med (2011) 208(6): 1243-52. doi:10.1084/jem.20102477

78. Rookhuizen DC, DeFranco AL. Toll-like receptor 9 signaling acts on multiple elements of the germinal center to enhance antibody responses. Proc Natl Acad Sci U S A (2014) 111(31):E3224-33. doi:10.1073/pnas.1323985111

79. Garcia De Vinuesa C, Gulbranson-Judge A, Khan M, O'Leary P, Cascalho M, Wabl M, et al. Dendritic cells associated with plasmablast survival. Eur J Immunol (1999) 29(11):3712-21. doi:10.1002/(SICI)1521-4141(199911)29: $11<3712::$ AID-IMMU3712>3.0.CO;2-P

80. Lee SK, Rigby RJ, Zotos D, Tsai LM, Kawamoto S, Marshall JL, et al. B cell priming for extrafollicular antibody responses requires Bcl-6 expression by T cells. J Exp Med (2011) 208(7):1377-88. doi:10.1084/jem.20102065

81. Blink EJ, Light A, Kallies A, Nutt SL, Hodgkin PD, Tarlinton DM. Early appearance of germinal center-derived memory B cells and plasma cells in blood after primary immunization.J Exp Med (2005) 201(4):545. doi:10.1084/ jem. 20042060 
82. Toyama H, Okada S, Hatano M, Takahashi Y, Takeda N, Ichii H, et al. Memory $\mathrm{B}$ cells without somatic hypermutation are generated from Bcl6-deficient B cells. Immunity (2002) 17(3):329-39. doi:10.1016/S1074-7613(02)00387-4

83. Di Niro R, Lee SJ, Vander Heiden JA, Elsner RA, Trivedi N, Bannock JM, et al. Salmonella infection drives promiscuous B cell activation followed by extrafollicular affinity maturation. Immunity (2015) 43(1):120-31. doi:10.1016/j. immuni.2015.06.013

84. Wang X, Cho B, Suzuki K, Xu Y, Green JA, An J, et al. Follicular dendritic cells help establish follicle identity and promote B cell retention in germinal centers. J Exp Med (2011) 208(12):2497-510. doi:10.1084/jem.20111449

85. Heesters BA, Chatterjee P, Kim YA, Gonzalez SF, Kuligowski MP, Kirchhausen T, et al. Endocytosis and recycling of immune complexes by follicular dendritic cells enhances B cell antigen binding and activation. Immunity (2013) 38(6):1164-75. doi:10.1016/j.immuni.2013.02.023

86. Gatto D, Brink R. The germinal center reaction. J Allergy Clin Immunol (2010) 126(5):898-907. doi:10.1016/j.jaci.2010.09.007

87. Legler DF, Loetscher M, Roos RS, Clark-Lewis I, Baggiolini M, Moser B. B cell-attracting chemokine 1, a human CXC chemokine expressed in lymphoid tissues, selectively attracts B lymphocytes via BLR1/CXCR5. J Exp Med (1998) 187(4):655-60. doi:10.1084/jem.187.4.655

88. Allen CD, Okada T, Tang HL, Cyster JG. Imaging of germinal center selection events during affinity maturation. Science (2007) 315(5811):528-31. doi:10.1126/science.1136736

89. Qi H, Cannons JL, Klauschen F, Schwartzberg PL, Germain RN. SAP-controlled T-B cell interactions underlie germinal centre formation. Nature (2008) 455(7214):764-9. doi:10.1038/nature07345

90. Cortini A, Ellinghaus U, Malik TH, Cunninghame Graham DS, Botto M, Vyse TJ. B cell OX40L supports T follicular helper cell development and contributes to SLE pathogenesis. Ann Rheum Dis (2017) 76(12):2095-103. doi:10.1136/annrheumdis-2017-211499

91. Good-Jacobson KL, Song E, Anderson S, Sharpe AH, Shlomchik MJ. CD80 expression on $\mathrm{B}$ cells regulates murine $\mathrm{T}$ follicular helper development, germinal center B cell survival, and plasma cell generation. J Immunol (2012) 188(9):4217-25. doi:10.4049/jimmunol.1102885

92. Kitano M, Moriyama S, Ando Y, Hikida M, Mori Y, Kurosaki T, et al. Bcl6 protein expression shapes pre-germinal center B cell dynamics and follicular helper T cell heterogeneity. Immunity (2011) 34(6):961-72. doi:10.1016/ j.immuni.2011.03.025

93. Noelle RJ, Ledbetter JA, Aruffo A. CD40 and its ligand, an essential ligandreceptor pair for thymus-dependent B-cell activation. Immunol Today (1992) 13(11):431-3.

94. Allen RC, Armitage RJ, Conley ME, Rosenblatt H, Jenkins NA, Copeland NG, et al. CD40 ligand gene defects responsible for X-linked hyper-IgM syndrome. Science (1993) 259(5097):990-3. doi:10.1126/science.7679801

95. Taylor JJ, Pape KA, Jenkins MK. A germinal center-independent pathway generates unswitched memory B cells early in the primary response. J Exp Med (2012) 209(3):597-606. doi:10.1084/jem.20111696

96. Linterman MA, Beaton L, Yu D, Ramiscal RR, Srivastava M, Hogan JJ, et al. IL-21 acts directly on B cells to regulate Bcl-6 expression and germinal center responses. J Exp Med (2010) 207(2):353-63. doi:10.1084/jem.20091738

97. El Shikh ME, El Sayed RM, Sukumar S, Szakal AK, Tew JG. Activation of B cells by antigens on follicular dendritic cells. Trends Immunol (2010) 31(6):205-11. doi:10.1016/j.it.2010.03.002

98. Ersching J, Efeyan A, Mesin L, Jacobsen JT, Pasqual G, Grabiner BC, et al. Germinal center selection and affinity maturation require dynamic regulation of mTORC1 kinase. Immunity (2017) 46(6):1045-58e6. doi:10.1016/j.immuni. 2017.06.005

99. Gitlin AD, Shulman Z, Nussenzweig MC. Clonal selection in the germinal centre by regulated proliferation and hypermutation. Nature (2014) 509(7502): 637-40. doi:10.1038/nature 13300

100. Victora GD, Schwickert TA, Fooksman DR, Kamphorst AO, Meyer-Hermann M, Dustin ML, et al. Germinal center dynamics revealed by multiphoton microscopy with a photoactivatable fluorescent reporter. Cell (2010) 143(4): 592-605. doi:10.1016/j.cell.2010.10.032

101. Klein U, Dalla-Favera R. Germinal centres: role in B-cell physiology and malignancy. Nat Rev Immunol (2008) 8(1):22-33. doi:10.1038/nri2217

102. Hao Z, Duncan GS, Seagal J, Su YW, Hong C, Haight J, et al. Fas receptor expression in germinal-center $\mathrm{B}$ cells is essential for $\mathrm{T}$ and $\mathrm{B}$ lymphocyte homeostasis. Immunity (2008) 29(4):615-27. doi:10.1016/j. immuni.2008.07.016

103. Chan TD, Wood K, Hermes JR, Butt D, Jolly CJ, Basten A, et al. Elimination of germinal-center-derived self-reactive $\mathrm{B}$ cells is governed by the location and concentration of self-antigen. Immunity (2012) 37(5):893-904. doi:10.1016/ j.immuni.2012.07.017

104. Mayer CT, Gazumyan A, Kara EE, Gitlin AD, Golijanin J, Viant C, et al. The microanatomic segregation of selection by apoptosis in the germinal center. Science (2017) 358(6360):eaao2602. doi:10.1126/science.aao2602

105. Shinnakasu R, Inoue T, Kometani K, Moriyama S, Adachi Y, Nakayama M, et al. Regulated selection of germinal-center cells into the memory B cell compartment. Nat Immunol (2016) 17(7):861-9. doi:10.1038/ni.3460

106. Smith KG, Light A, O’Reilly LA, Ang SM, Strasser A, Tarlinton D. Bcl-2 transgene expression inhibits apoptosis in the germinal center and reveals differences in the selection of memory B cells and bone marrow antibody-forming cells. J Exp Med (2000) 191(3):475-84. doi:10.1084/jem.191.3.475

107. Smith KG, Light A, Nossal GJ, Tarlinton DM. The extent of affinity maturation differs between the memory and antibody-forming cell compartments in the primary immune response. EMBO J (1997) 16(11):2996-3006. doi:10.1093/ emboj/16.11.2996

108. Krautler NJ, Suan D, Butt D, Bourne K, Hermes JR, Chan TD, et al. Differentiation of germinal center B cells into plasma cells is initiated by high-affinity antigen and completed by Th cells. J Exp Med (2017) 214(5):1259-67. doi:10.1084/jem.20161533

109. Weisel FJ, Zuccarino-Catania GV, Chikina M, Shlomchik MJ. A temporal switch in the germinal center determines differential output of memory B and plasma cells. Immunity (2016) 44(1):116-30. doi:10.1016/j.immuni.2015. 12.004

110. Zotos D, Coquet JM, Zhang Y, Light A, D’Costa K, Kallies A, et al. IL-21 regulates germinal center $\mathrm{B}$ cell differentiation and proliferation through a B cell-intrinsic mechanism. J Exp Med (2010) 207(2):365-78. doi:10.1084/ jem.20091777

111. Moens L, Tangye SG. Cytokine-mediated regulation of plasma cell generation: IL-21 takes center stage. Front Immunol (2014) 5:65. doi:10.3389/fimmu. 2014.00065

112. Kasturi SP, Skountzou I, Albrecht RA, Koutsonanos D, Hua T, Nakaya HI, et al. Programming the magnitude and persistence of antibody responses with innate immunity. Nature (2011) 470(7335):543-7. doi:10.1038/nature 09737

113. Gavin AL, Hoebe K, Duong B, Ota T, Martin C, Beutler B, et al. Adjuvantenhanced antibody responses in the absence of toll-like receptor signaling. Science (2006) 314(5807):1936-8. doi:10.1126/science.1135299

114. Meyer-Bahlburg A, Khim S, Rawlings DJ. B cell intrinsic TLR signals amplify but are not required for humoral immunity. J Exp Med (2007) 204(13): 3095-101. doi:10.1084/jem.20071250

115. Suan D, Sundling C, Brink R. Plasma cell and memory B cell differentiation from the germinal center. Curr Opin Immunol (2017) 45:97-102. doi:10.1016/ j.coi.2017.03.006

116. Chiu YK, Lin IY, Su ST, Wang KH, Yang SY, Tsai DY, et al. Transcription factor ABF-1 suppresses plasma cell differentiation but facilitates memory B cell formation. J Immunol (2014) 193(5):2207-17. doi:10.4049/jimmunol. 1400411

117. Reimold AM, Iwakoshi NN, Manis J, Vallabhajosyula P, Szomolanyi-Tsuda E, Gravallese EM, et al. Plasma cell differentiation requires the transcription factor XBP-1. Nature (2001) 412(6844):300-7. doi:10.1038/35085509

118. Minnich M, Tagoh H, Bonelt P, Axelsson E, Fischer M, Cebolla B, et al. Multifunctional role of the transcription factor Blimp-1 in coordinating plasma cell differentiation. Nat Immunol (2016) 17(3):331-43. doi:10.1038/ ni.3349

119. Sciammas R, Shaffer AL, Schatz JH, Zhao H, Staudt LM, Singh H. Graded expression of interferon regulatory factor-4 coordinates isotype switching with plasma cell differentiation. Immunity (2006) 25(2):225-36. doi:10.1016/j.immuni.2006.07.009

120. Nera KP, Kohonen P, Narvi E, Peippo A, Mustonen L, Terho P, et al. Loss of Pax5 promotes plasma cell differentiation. Immunity (2006) 24(3):283-93. doi:10.1016/j.immuni.2006.02.003

121. Shaffer AL, Lin KI, Kuo TC, Yu X, Hurt EM, Rosenwald A, et al. Blimp-1 orchestrates plasma cell differentiation by extinguishing the mature B cell 
gene expression program. Immunity (2002) 17(1):51-62. doi:10.1016/ S1074-7613(02)00335-7

122. Shaffer AL, Shapiro-Shelef M, Iwakoshi NN, Lee AH, Qian SB, Zhao H, et al. XBP1, downstream of Blimp-1, expands the secretory apparatus and other organelles, and increases protein synthesis in plasma cell differentiation. Immunity (2004) 21(1):81-93. doi:10.1016/j.immuni.2004. 06.010

123. Meyer-Hermann M, Mohr E, Pelletier N, Zhang Y, Victora GD, Toellner KM. A theory of germinal center B cell selection, division, and exit. Cell Rep (2012) 2(1):162-74. doi:10.1016/j.celrep.2012.05.010

124. Mohr E, Serre K, Manz RA, Cunningham AF, Khan M, Hardie DL, et al. Dendritic cells and monocyte/macrophages that create the IL-6/APRIL-rich lymph node microenvironments where plasmablasts mature. J Immunol (2009) 182(4):2113-23. doi:10.4049/jimmunol.0802771

125. Tipton CM, Fucile CF, Darce J, Chida A, Ichikawa T, Gregoretti I, et al. Diversity, cellular origin and autoreactivity of antibody-secreting cell population expansions in acute systemic lupus erythematosus. Nat Immunol (2015) 16(7):755-65. doi:10.1038/ni.3175

126. Slifka MK, Antia R, Whitmire JK, Ahmed R. Humoral immunity due to long-lived plasma cells. Immunity (1998) 8(3):363-72. doi:10.1016/ S1074-7613(00)80541-5

127. Manz RA, Thiel A, Radbruch A. Lifetime of plasma cells in the bone marrow. Nature (1997) 388(6638):133-4. doi:10.1038/40540

128. Hammarlund E, Thomas A, Amanna IJ, Holden LA, Slayden OD, Park B, et al. Plasma cell survival in the absence of B cell memory. Nat Commun (2017) 8(1):1781. doi:10.1038/s41467-017-01901-w

129. Bhoj VG, Arhontoulis D, Wertheim G, Capobianchi J, Callahan CA, Ellebrecht CT, et al. Persistence of long-lived plasma cells and humoral immunity in individuals responding to CD19-directed CAR T-cell therapy. Blood (2016) 128(3):360-70. doi:10.1182/blood-2016-01-694356

130. Hiepe F, Radbruch A. Plasma cells as an innovative target in autoimmune disease with renal manifestations. Nat Rev Nephrol (2016) 12(4):232-40. doi:10.1038/nrneph.2016.20

131. Taddeo A, Khodadadi L, Voigt C, Mumtaz IM, Cheng Q, Moser K, et al. Long-lived plasma cells are early and constantly generated in New Zealand Black/New Zealand White F1 mice and their therapeutic depletion requires a combined targeting of autoreactive plasma cells and their precursors. Arthritis Res Ther (2015) 17:39. doi:10.1186/s13075-015-0551-3

132. Sze DM, Toellner KM, Garcia de Vinuesa C, Taylor DR, MacLennan IC. Intrinsic constraint on plasmablast growth and extrinsic limits of plasma cell survival. J Exp Med (2000) 192(6):813-21. doi:10.1084/jem.192.6.813

133. Minges Wols HA, Ippolito JA, Yu Z, Palmer JL, White FA, Le PT, et al. The effects of microenvironment and internal programming on plasma cell survival. Int Immunol (2007) 19(7):837-46. doi:10.1093/intimm/ dxm051

134. Kometani K, Kurosaki T. Differentiation and maintenance of long-lived plasma cells. Curr Opin Immunol (2015) 33:64-9. doi:10.1016/j.coi.2015. 01.017

135. Tarte K, Zhan F, De Vos J, Klein B, Shaughnessy J Jr. Gene expression profiling of plasma cells and plasmablasts: toward a better understanding of the late stages of B-cell differentiation. Blood (2003) 102(2):592-600. doi:10.1182/ blood-2002-10-3161

136. Tokoyoda K, Egawa T, Sugiyama T, Choi BI, Nagasawa T. Cellular niches controlling B lymphocyte behavior within bone marrow during development. Immunity (2004) 20(6):707-18. doi:10.1016/j.immuni.2004.05.001

137. Chu VT, Frohlich A, Steinhauser G, Scheel T, Roch T, Fillatreau S, et al. Eosinophils are required for the maintenance of plasma cells in the bone marrow. Nat Immunol (2011) 12(2):151-9. doi:10.1038/ni.1981

138. Wilmore JR, Allman D. Here, there, and anywhere? Arguments for and against the physical plasma cell survival niche. I Immunol (2017) 199(3):839-45. doi:10.4049/jimmunol.1700461

139. Belnoue E, Pihlgren M, McGaha TL, Tougne C, Rochat AF, Bossen C, et al. APRIL is critical for plasmablast survival in the bone marrow and poorly expressed by early-life bone marrow stromal cells. Blood (2008) 111(5):2755-64. doi:10.1182/blood-2007-09-110858

140. Benson MJ, Dillon SR, Castigli E, Geha RS, Xu S, Lam KP, et al. Cutting edge: the dependence of plasma cells and independence of memory B cells on BAFF and APRIL. JImmunol (2008) 180(6):3655-9. doi:10.4049/ jimmunol.180.6.3655
141. O’Connor BP, Raman VS, Erickson LD, Cook WJ, Weaver LK, Ahonen C, et al. BCMA is essential for the survival of long-lived bone marrow plasma cells. J Exp Med (2004) 199(1):91-8. doi:10.1084/jem.20031330

142. Mahevas M, Michel M, Weill JC, Reynaud CA. Long-lived plasma cells in autoimmunity: lessons from B-cell depleting therapy. Front Immunol (2013) 4:494. doi:10.3389/fimmu.2013.00494

143. Mahevas M, Patin P, Huetz F, Descatoire M, Cagnard N, Bole-Feysot C, et al. B cell depletion in immune thrombocytopenia reveals splenic long-lived plasma cells. J Clin Invest (2013) 123(1):432-42. doi:10.1172/JCI65689

144. Rozanski CH, Arens R, Carlson LM, Nair J, Boise LH, Chanan-Khan AA, et al. Sustained antibody responses depend on CD28 function in bone marrow-resident plasma cells. J Exp Med (2011) 208(7):1435-46. doi:10.1084/ jem. 20110040

145. Chevrier S, Genton C, Kallies A, Karnowski A, Otten LA, Malissen B, et al. CD93 is required for maintenance of antibody secretion and persistence of plasma cells in the bone marrow niche. Proc Natl Acad Sci U S A (2009) 106(10):3895-900. doi:10.1073/pnas.0809736106

146. Hsu MC, Toellner KM, Vinuesa CG, Maclennan IC. B cell clones that sustain long-term plasmablast growth in T-independent extrafollicular antibody responses. Proc Natl Acad Sci U S A (2006) 103(15):5905-10. doi:10.1073/ pnas. 0601502103

147. Bortnick A, Chernova I, Quinn WJ III, Mugnier M, Cancro MP, Allman D. Long-lived bone marrow plasma cells are induced early in response to $\mathrm{T}$ cell-independent or T cell-dependent antigens. JImmunol (2012) 188(11):5389-96. doi:10.4049/jimmunol.1102808

148. Sanderson NS, Zimmermann M, Eilinger L, Gubser C, Schaeren-Wiemers N, Lindberg RL, et al. Cocapture of cognate and bystander antigens can activate autoreactive B cells. Proc Natl Acad Sci U S A (2017) 114(4):734-9. doi:10.1073/pnas.1614472114

149. Son M, Santiago-Schwarz F, Al-Abed Y, Diamond B. C1q limits dendritic cell differentiation and activation by engaging LAIR-1. Proc Natl Acad Sci U S A (2012) 109(46):E3160-7. doi:10.1073/pnas.1212753109

150. Hess C, Winkler A, Lorenz AK, Holecska V, Blanchard V, Eiglmeier S, et al. T cell-independent B cell activation induces immunosuppressive sialylated IgG antibodies. J Clin Invest (2013) 123(9):3788-96. doi:10.1172/ JCI65938

151. Pfeifle R, Rothe T, Ipseiz N, Scherer HU, Culemann S, Harre U, et al. Regulation of autoantibody activity by the IL-23-TH17 axis determines the onset of autoimmune disease. Nat Immunol (2017) 18(1):104-13. doi:10.1038/ni.3579

152. Klinman NR. The "clonal selection hypothesis" and current concepts of B cell tolerance.Immunity (1996)5(3):189-95.doi:10.1016/S1074-7613(00)80314-3

153. Linton PJ, Rudie A, Klinman NR. Tolerance susceptibility of newly generating memory B cells. J Immunol (1991) 146(12):4099-104.

154. Malkiel S, Jeganathan V, Wolfson S, Manjarrez Orduno N, Marasco E, Aranow C, et al. Checkpoints for autoreactive B cells in the peripheral blood of lupus patients assessed by flow cytometry. Arthritis Rheumatol (2016) 68(9): 2210-20. doi:10.1002/art.39710

155. Cappione A III, Anolik JH, Pugh-Bernard A, Barnard J, Dutcher P, Silverman G, et al. Germinal center exclusion of autoreactive B cells is defective in human systemic lupus erythematosus. J Clin Invest (2005) 115(11):3205-16. doi:10.1172/JCI24179

156. Sabouri Z, Schofield P, Horikawa K, Spierings E, Kipling D, Randall KL, et al. Redemption of autoantibodies on anergic B cells by variable-region glycosylation and mutation away from self-reactivity. Proc Natl Acad Sci U S A (2014) 111(25):E2567-75. doi:10.1073/pnas.1406974111

157. Reed JH, Jackson J, Christ D, Goodnow CC. Clonal redemption of autoantibodies by somatic hypermutation away from self-reactivity during human immunization. J Exp Med (2016) 213(7):1255-65. doi:10.1084/jem.20151978

158. Ait-Azzouzene D, Kono DH, Gonzalez-Quintial R, McHeyzer-Williams LJ, Lim M, Wickramarachchi D, et al. Deletion of IgG-switched autoreactive B cells and defects in Fas(lpr) lupus mice. J Immunol (2010) 185(2):1015-27. doi:10.4049/jimmunol.1000698

159. Rice JS, Newman J, Wang C, Michael DJ, Diamond B. Receptor editing in peripheral B cell tolerance. Proc Natl Acad Sci U S A (2005) 102(5):1608-13. doi:10.1073/pnas.0409217102

160. Hande S, Notidis E, Manser T. Bcl-2 obstructs negative selection of autoreactive, hypermutated antibody $\mathrm{V}$ regions during memory B cell development. Immunity (1998) 8(2):189-98. doi:10.1016/S1074-7613(00)80471-9 
161. Notidis E, Heltemes L, Manser T. Dominant, hierarchical induction of peripheral tolerance during foreign antigen-driven B cell development. Immunity (2002) 17(3):317-27. doi:10.1016/S1074-7613(02)00392-8

162. Pulendran B, Kannourakis G, NouriS, Smith KG,Nossal GJ. Solubleantigencan cause enhanced apoptosis of germinal-centre B cells. Nature (1995) 375(6529): 331-4. doi:10.1038/375331a0

163. Wang YH, Diamond B. B cell receptor revision diminishes the autoreactive B cell response after antigen activation in mice. J Clin Invest (2008) 118(8): 2896-907. doi:10.1172/JCI35618

164. Scheid JF, Mouquet H, Kofer J, Yurasov S, Nussenzweig MC, Wardemann H. Differential regulation of self-reactivity discriminates between IgG+ human circulating memory B cells and bone marrow plasma cells. Proc Natl Acad Sci U S A (2011) 108(44):18044-8. doi:10.1073/pnas.1113395108

165. Pelletier N, McHeyzer-Williams LJ, Wong KA, Urich E, Fazilleau N, McHeyzer-Williams MG. Plasma cells negatively regulate the follicular helper T cell program. Nat Immunol (2010) 11(12):1110-8. doi:10.1038/ni.1954

166. William J, Euler C, Christensen S, Shlomchik MJ. Evolution of autoantibody responses via somatic hypermutation outside of germinal centers. Science (2002) 297(5589):2066-70. doi:10.1126/science.1073924

167. Deng R, Hurtz C, Song Q, Yue C, Xiao G, Yu H, et al. Extrafollicular CD4+ T-B interactions are sufficient for inducing autoimmune-like chronic graftversus-host disease. Nat Commun (2017) 8(1):978. doi:10.1038/s41467017-00880-2

168. Odegard JM, Marks BR, DiPlacido LD, Poholek AC, Kono DH, Dong C, et al. ICOS-dependent extrafollicular helper T cells elicit IgG production via IL-21 in systemic autoimmunity. J Exp Med (2008) 205(12):2873-86. doi:10.1084/ jem.20080840

169. Luzina IG, Atamas SP, Storrer CE, daSilva LC, Kelsoe G, Papadimitriou JC, et al. Spontaneous formation of germinal centers in autoimmune mice. J Leukoc Biol (2001) 70(4):578-84. doi:10.1189/jlb.70.4.578

170. Li Y, Li H, Weigert M. Autoreactive B cells in the marginal zone that express dual receptors. J Exp Med (2002) 195(2):181-8. doi:10.1084/jem.20011453

171. Julien S, Soulas P, Garaud JC, Martin T, Pasquali JL. B cell positive selection by soluble self-antigen. J Immunol (2002) 169(8):4198-204. doi:10.4049/ jimmunol.169.8.4198

172. Cariappa A, Tang M, Parng C, Nebelitskiy E, Carroll M, Georgopoulos K, et al. The follicular versus marginal zone B lymphocyte cell fate decision is regulated by Aiolos, Btk, and CD21. Immunity (2001) 14(5):603-15. doi:10.1016/ S1074-7613(01)00135-2

173. Martin F, Kearney JF. Positive selection from newly formed to marginal zone $\mathrm{B}$ cells depends on the rate of clonal production, $\mathrm{CD} 19$, and btk. Immunity (2000) 12(1):39-49. doi:10.1016/S1074-7613(00)80157-0

174. Cerutti A, Cols M, Puga I. Marginal zone B cells: virtues of innate-like antibody-producing lymphocytes. Nat Rev Immunol (2013) 13(2):118-32. doi:10.1038/nri3383

175. Phan TG, Gardam S, Basten A, Brink R. Altered migration, recruitment, and somatic hypermutation in the early response of marginal zone B cells to T cell-dependent antigen. J Immunol (2005) 174(8):4567-78. doi:10.4049/ jimmunol.174.8.4567

176. Zhou Z, Niu H, Zheng YY, Morel L. Autoreactive marginal zone B cells enter the follicles and interact with CD4+ T cells in lupus-prone mice. $B M C$ Immunol (2011) 12:7. doi:10.1186/1471-2172-12-7

177. Grimaldi CM, Michael DJ, Diamond B. Cutting edge: expansion and activation of a population of autoreactive marginal zone B cells in a model of estrogen-induced lupus. J Immunol (2001) 167(4):1886-90. doi:10.4049/ jimmunol.167.4.1886

178. Wither JE, Loh C, Lajoie G, Heinrichs S, Cai YC, Bonventi G, et al. Colocalization of expansion of the splenic marginal zone population with abnormal B cell activation and autoantibody production in B6 mice with an introgressed New Zealand Black chromosome 13 interval. J Immunol (2005) 175(7):4309-19. doi:10.4049/jimmunol.175.7.4309

179. Atencio S, Amano H, Izui S, Kotzin BL. Separation of the New Zealand Black genetic contribution to lupus from New Zealand Black determined expansions of marginal zone B and B1a cells. J Immunol (2004) 172(7):4159-66. doi:10.4049/jimmunol.172.7.4159

180. Amano H, Amano E, Moll T, Marinkovic D, Ibnou-Zekri N, Martinez-Soria E, et al. The Yaa mutation promoting murine lupus causes defective development of marginal zone B cells. J Immunol (2003) 170(5):2293-301. doi:10.4049/ jimmunol.170.5.2293
181. Nickerson KM, Christensen SR, Shupe J, Kashgarian M, Kim D, Elkon K, et al. TLR9 regulates TLR7- and MyD88-dependent autoantibody production and disease in a murine model of lupus. J Immunol (2010) 184(4): 1840-8. doi:10.4049/jimmunol.0902592

182. Teichmann LL, Schenten D, Medzhitov R, Kashgarian M, Shlomchik MJ. Signals via the adaptor MyD88 in B cells and DCs make distinct and synergistic contributions to immune activation and tissue damage in lupus. Immunity (2013) 38(3):528-40. doi:10.1016/j.immuni.2012.11.017

183. Christensen SR, Kashgarian M, Alexopoulou L, Flavell RA, Akira S, Shlomchik MJ. Toll-like receptor 9 controls anti-DNA autoantibody production in murine lupus. J Exp Med (2005) 202(2):321-31. doi:10.1084/jem. 20050338

184. Christensen SR, Shupe J, Nickerson K, Kashgarian M, Flavell RA, Shlomchik MJ. Toll-like receptor 7 and TLR9 dictate autoantibody specificity and have opposing inflammatory and regulatory roles in a murine model of lupus. Immunity (2006) 25(3):417-28. doi:10.1016/j.immuni.2006.07.013

185. Teichmann LL, Ols ML, Kashgarian M, Reizis B, Kaplan DH, Shlomchik MJ. Dendritic cells in lupus are not required for activation of $\mathrm{T}$ and $\mathrm{B}$ cells but promote their expansion, resulting in tissue damage. Immunity (2010) 33(6): 967-78. doi:10.1016/j.immuni.2010.11.025

186. Wong CK, Wong PT, Tam LS, Li EK, Chen DP, Lam CW. Activation profile of toll-like receptors of peripheral blood lymphocytes in patients with systemic lupus erythematosus. Clin Exp Immunol (2010) 159(1):11-22. doi:10.1111/j.1365-2249.2009.04036.x

187. Flores-Borja F, Kabouridis PS, Jury EC, Isenberg DA, Mageed RA. Decreased Lyn expression and translocation to lipid raft signaling domains in B lymphocytes from patients with systemic lupus erythematosus. Arthritis Rheum (2005) 52(12):3955-65. doi:10.1002/art.21416

188. Pritchard NR, Cutler AJ, Uribe S, Chadban SJ, Morley BJ, Smith KG. Autoimmune-prone mice share a promoter haplotype associated with reduced expression and function of the Fc receptor FcgammaRII. Curr Biol (2000) 10(4):227-30. doi:10.1016/S0960-9822(00)00344-4

189. Suurmond J, Calise J, Malkiel S, Diamond B. DNA-reactive B cells in lupus. Curr Opin Immunol (2016) 43:1-7. doi:10.1016/j.coi.2016.07.002

190. Chaturvedi A, Dorward D, Pierce SK. The B cell receptor governs the subcellular location of toll-like receptor 9 leading to hyperresponses to DNA-containing antigens. Immunity (2008) 28(6):799-809. doi:10.1016/j.immuni.2008. 03.019

191. Lau CM, Broughton C, Tabor AS, Akira S, Flavell RA, Mamula MJ, et al. RNA-associated autoantigens activate B cells by combined B cell antigen receptor/toll-like receptor 7 engagement. J Exp Med (2005) 202(9):1171-7. doi:10.1084/jem.20050630

192. Poovassery JS, Bishop GA. Type I IFN receptor and the B cell antigen receptor regulate TLR7 responses via distinct molecular mechanisms. J Immunol (2012) 189(4):1757-64. doi:10.4049/jimmunol.1200624

193. Boes M, Schmidt T, Linkemann K, Beaudette BC, Marshak-Rothstein A, Chen J. Accelerated development of IgG autoantibodies and autoimmune disease in the absence of secreted IgM. Proc Natl Acad Sci U S A (2000) 97(3):1184-9. doi:10.1073/pnas.97.3.1184

194. Haynes NM, Allen CD, Lesley R, Ansel KM, Killeen N, Cyster JG. Role of CXCR5 and CCR7 in follicular Th cell positioning and appearance of a programmed cell death gene-1high germinal center-associated subpopulation. J Immunol (2007) 179(8):5099-108. doi:10.4049/jimmunol.179.8.5099

195. Elsner RA, Ernst DN, Baumgarth N. Single and coexpression of CXCR4 and CXCR5 identifies CD4 T helper cells in distinct lymph node niches during influenza virus infection. J Virol (2012) 86(13):7146-57. doi:10.1128/ JVI.06904-11

196. Herlands RA, Christensen SR, Sweet RA, Hershberg U, Shlomchik MJ. $\mathrm{T}$ cell-independent and toll-like receptor-dependent antigen-driven activation of autoreactive B cells. Immunity (2008) 29(2):249-60. doi:10.1016/j.immuni. 2008.06.009

197. Wang L, Zhao P, Ma L, Shan Y, Jiang Z, Wang J, et al. Increased interleukin 21 and follicular helper T-like cells and reduced interleukin 10+ B cells in patients with new-onset systemic lupus erythematosus. J Rheumatol (2014) 41(9):1781-92. doi:10.3899/jrheum.131025

198. He B, Qiao X, Cerutti A. CpG DNA induces IgG class switch DNA recombination by activating human $B$ cells through an innate pathway that requires TLR9 and cooperates with IL-10. J Immunol (2004) 173(7):4479-91. doi:10.4049/jimmunol.173.7.4479 
199. Sweet RA, Christensen SR, Harris ML, Shupe J, Sutherland JL, Shlomchik MJ. A new site-directed transgenic rheumatoid factor mouse model demonstrates extrafollicular class switch and plasmablast formation. Autoimmunity (2010) 43(8):607-18. doi:10.3109/08916930903567500

200. Arce E, Jackson DG, Gill MA, Bennett LB, Banchereau J, Pascual V. Increased frequency of pre-germinal center $B$ cells and plasma cell precursors in the blood of children with systemic lupus erythematosus. J Immunol (2001) 167(4):2361-9. doi:10.4049/jimmunol.167.4.2361

201. Zhang X, Lindwall E, Gauthier C, Lyman J, Spencer N, Alarakhia A, et al. Circulating CXCR5+CD4+helper T cells in systemic lupus erythematosus patients share phenotypic properties with germinal center follicular helper T cells and promote antibody production. Lupus (2015) 24(9):909-17. doi:10.1177/0961203314567750

202. Brink R. The imperfect control of self-reactive germinal center B cells. Curr Opin Immunol (2014) 28:97-101. doi:10.1016/j.coi.2014.03.001

203. Guo W, Smith D, Aviszus K, Detanico T, Heiser RA, Wysocki LJ. Somatic hypermutation as a generator of antinuclear antibodies in a murine model of systemic autoimmunity. J Exp Med (2010) 207(10):2225-37. doi:10.1084/jem.20092712

204. Mietzner B, Tsuiji M, Scheid J, Velinzon K, Tiller T, Abraham K, et al. Autoreactive IgG memory antibodies in patients with systemic lupus erythematosus arise from nonreactive and polyreactive precursors. Proc Natl Acad Sci U S A (2008) 105(28):9727-32. doi:10.1073/pnas.0803644105

205. Paul E, Nelde A, Verschoor A, Carroll MC. Follicular exclusion of autoreactive B cells requires FcgammaRIIb. Int Immunol (2007) 19(4):365-73. doi:10.1093/intimm/dxm002

206. Dai X, James RG, Habib T, Singh S, Jackson S, Khim S, et al. A disease-associated PTPN22 variant promotes systemic autoimmunity in murine models. J Clin Invest (2013) 123(5):2024-36. doi:10.1172/JCI66963

207. Nowosad CR, Spillane KM, Tolar P. Germinal center B cells recognize antigen through a specialized immune synapse architecture. Nat Immunol (2016) 17(7):870-7. doi:10.1038/ni.3458

208. Walsh ER, Pisitkun P, Voynova E, Deane JA, Scott BL, Caspi RR, et al. Dual signaling by innate and adaptive immune receptors is required for TLR7induced B-cell-mediated autoimmunity. Proc Natl Acad Sci U S A (2012) 109(40):16276-81. doi:10.1073/pnas.1209372109

209. Jackson SW, Scharping NE, Kolhatkar NS, Khim S, Schwartz MA, Li QZ, et al. Opposing impact of B cell-intrinsic TLR7 and TLR9 signals on autoantibody repertoire and systemic inflammation. J Immunol (2014) 192(10):4525-32. doi:10.4049/jimmunol.1400098

210. Das A, Heesters BA, Bialas A, O’Flynn J, Rifkin IR, Ochando J, et al. Follicular dendritic cell activation by TLR Ligands promotes autoreactive B cell responses. Immunity (2017) 46(1):106-19. doi:10.1016/j.immuni.2016. 12.014

211. Woods M, Zou YR, Davidson A. Defects in germinal center selection in SLE. Front Immunol (2015) 6:425. doi:10.3389/fimmu.2015.00425

212. Diamond B, Scharff MD. Somatic mutation of the T15 heavy chain gives rise to an antibody with autoantibody specificity. Proc Natl Acad Sci U S A (1984) 81(18):5841-4. doi:10.1073/pnas.81.18.5841

213. Zhang J, Roschke V, Baker KP, Wang Z, Alarcon GS, Fessler BJ, et al. Cutting edge: a role for B lymphocyte stimulator in systemic lupus erythematosus. J Immunol (2001) 166(1):6-10. doi:10.4049/jimmunol.166.1.6

214. Coquery CM, Loo WM, Wade NS, Bederman AG, Tung KS, Lewis JE, et al. BAFF regulates follicular helper $t$ cells and affects their accumulation and interferon-gamma production in autoimmunity. Arthritis Rheumatol (2015) 67(3):773-84. doi:10.1002/art.38950

215. Mackay F, Woodcock SA, Lawton P, Ambrose C, Baetscher M, Schneider P, et al. Mice transgenic for BAFF develop lymphocytic disorders along with autoimmune manifestations. J Exp Med (1999) 190(11):1697-710. doi:10.1084/ jem.190.11.1697

216. Simpson N, Gatenby PA, Wilson A, Malik S, Fulcher DA, Tangye SG, et al. Expansion of circulating $\mathrm{T}$ cells resembling follicular helper $\mathrm{T}$ cells is a fixed phenotype that identifies a subset of severe systemic lupus erythematosus. Arthritis Rheum (2010) 62(1):234-44. doi:10.1002/art.25032

217. Nakou M, Papadimitraki ED, Fanouriakis A, Bertsias GK, Choulaki C, Goulidaki N, et al. Interleukin-21 is increased in active systemic lupus erythematosus patients and contributes to the generation of plasma B cells. Clin Exp Rheumatol (2013) 31(2):172-9.

218. Wong CK, Wong PT, Tam LS, Li EK, Chen DP, Lam CW. Elevated production of B cell chemokine CXCL13 is correlated with systemic lupus erythematosus disease activity. J Clin Immunol (2010) 30(1):45-52. doi:10.1007/s10875-009-9325-5

219. Linterman MA, Rigby RJ, Wong RK, Yu D, Brink R, Cannons JL, et al. Follicular helper $\mathrm{T}$ cells are required for systemic autoimmunity. J Exp Med (2009) 206(3):561-76. doi:10.1084/jem.20081886

220. Jacquemin C, Schmitt N, Contin-Bordes C, Liu Y, Narayanan P, Seneschal J, et al. OX40 ligand contributes to human lupus pathogenesis by promoting $\mathrm{T}$ follicular helper response. Immunity (2015) 42(6):1159-70. doi:10.1016/j. immuni.2015.05.012

221. Luo J, Niu X, Liu H, Zhang M, Chen M, Deng S. Up-regulation of transcription factor Blimp1 in systemic lupus erythematosus. Mol Immunol (2013) 56(4):574-82. doi:10.1016/j.molimm.2013.05.241

222. Guimaraes PM, Scavuzzi BM, Stadtlober NP, Franchi Santos L, Lozovoy MAB, Iriyoda TMV, et al. Cytokines in systemic lupus erythematosus: far beyond Th1/Th2 dualism lupus: cytokine profiles. Immunol Cell Biol (2017) 95(9): 824-31. doi:10.1038/icb.2017.53

223. Salazar-Camarena DC, Ortiz-Lazareno PC, Cruz A, Oregon-Romero E, Machado-Contreras JR, Munoz-Valle JF, et al. Association of BAFF, APRIL serum levels, BAFF-R, TACI and BCMA expression on peripheral B-cell subsets with clinical manifestations in systemic lupus erythematosus. Lupus (2016) 25(6):582-92. doi:10.1177/0961203315608254

224. Hoyer BF, Moser K, Hauser AE, Peddinghaus A, Voigt C, Eilat D, et al. Short-lived plasmablasts and long-lived plasma cells contribute to chronic humoral autoimmunity in NZB/W mice. J Exp Med (2004) 199(11):1577-84. doi:10.1084/jem.20040168

225. Lo MS, Zurakowski D, Son MB, Sundel RP. Hypergammaglobulinemia in the pediatric population as a marker for underlying autoimmune disease: a retrospective cohort study. Pediatr Rheumatol Online J (2013) 11(1):42. doi:10.1186/1546-0096-11-42

226. Cassese G, Lindenau S, de Boer B, Arce S, Hauser A, Riemekasten G, et al. Inflamed kidneys of NZB/W mice are a major site for the homeostasis of plasma cells. Eur J Immunol (2001) 31(9):2726-32. doi:10.1002/1521-4141 (200109)31:9<2726::AID-IMMU2726>3.0.CO;2-H

227. Starke C, Frey S, Wellmann U, Urbonaviciute V, Herrmann M, Amann K, et al. High frequency of autoantibody-secreting cells and long-lived plasma cells within inflamed kidneys of NZB/W F1 lupus mice. Eur J Immunol (2011) 41(7):2107-12. doi:10.1002/eji.201041315

228. Wang A, Fairhurst AM, Tus K, Subramanian S, Liu Y, Lin F, et al. CXCR4/ CXCL12 hyperexpression plays a pivotal role in the pathogenesis of lupus. J Immunol (2009) 182(7):4448-58. doi:10.4049/jimmunol.0801920

229. Deng Y, Tsao BP. Updates in lupus genetics. Curr Rheumatol Rep (2017) 19(11):68. doi:10.1007/s11926-017-0695-Z

230. Vaughn SE, Kottyan LC, Munroe ME, Harley JB. Genetic susceptibility to lupus: the biological basis of genetic risk found in B cell signaling pathways. J Leukoc Biol (2012) 92(3):577-91. doi:10.1189/jlb.0212095

231. Teruel M, Alarcon-Riquelme ME. The genetic basis of systemic lupus erythematosus: what are the risk factors and what have we learned. J Autoimmun (2016) 74:161-75. doi:10.1016/j.jaut.2016.08.001

232. Ghodke-Puranik Y, Niewold TB. Immunogenetics of systemic lupus erythematosus: a comprehensive review. J Autoimmun (2015) 64:125-36. doi:10.1016/ j.jaut.2015.08.004

233. Zhou XJ, Cheng FJ, Qi YY, Zhao MH, Zhang H. A replication study from Chinese supports association between lupus-risk allele in TNFSF4 and renal disorder. Biomed Res Int (2013) 2013:597921. doi:10.1155/2013/ 597921

234. Manku H, Langefeld CD, Guerra SG, Malik TH, Alarcon-Riquelme M, Anaya JM, et al. Trans-ancestral studies fine map the SLE-susceptibility locus TNFSF4. PLoS Genet (2013) 9(7):e1003554. doi:10.1371/journal.pgen. 1003554

235. Lamagna C, Hu Y, DeFranco AL, Lowell CA. B cell-specific loss of Lyn kinase leads to autoimmunity. J Immunol (2014) 192(3):919-28. doi:10.4049/ jimmunol.1301979

236. Hua Z, Gross AJ, Lamagna C, Ramos-Hernandez N, Scapini P, Ji M, et al. Requirement for MyD88 signaling in B cells and dendritic cells for germinal center anti-nuclear antibody production in Lyn-deficient mice. J Immunol (2014) 192(3):875-85. doi:10.4049/jimmunol.1300683

237. Simpfendorfer KR, Olsson LM, Manjarrez Orduno N, Khalili H, Simeone AM, Katz MS, et al. The autoimmunity-associated BLK haplotype exhibits cis-regulatory effects on mRNA and protein expression that are prominently 
observed in B cells early in development. Hum Mol Genet (2012) 21(17): 3918-25. doi:10.1093/hmg/dds220

238. Simpfendorfer KR, Armstead BE, Shih A, Li W, Curran M, Manjarrez-Orduno N, et al. Autoimmune disease-associated haplotypes of BLK exhibit lowered thresholds for B cell activation and expansion of Ig class-switched B cells. Arthritis Rheumatol (2015) 67(11):2866-76. doi:10.1002/art.39301

239. Samuelson EM, Laird RM, Maue AC, Rochford R, Hayes SM. Blk haploinsufficiency impairs the development, but enhances the functional responses, of MZ B cells. Immunol Cell Biol (2012) 90(6):620-9. doi:10.1038/icb. 2011.76

240. Texido G, Su IH, Mecklenbrauker I, Saijo K, Malek SN, Desiderio S, et al. The B-cell-specific Src-family kinase Blk is dispensable for B-cell development and activation. Mol Cell Biol (2000) 20(4):1227-33. doi:10.1128/MCB. 20.4.1227-1233.2000

241. Kozyrev SV, Abelson AK, Wojcik J, Zaghlool A, Linga Reddy MV, Sanchez E, et al. Functional variants in the B-cell gene BANK1 are associated with systemic lupus erythematosus. Nat Genet (2008) 40(2):211-6. doi:10.1038/ng.79

242. Yokoyama K, Su Ih IH, Tezuka T, Yasuda T, Mikoshiba K, Tarakhovsky A, et al. BANK regulates BCR-induced calcium mobilization by promoting tyrosine phosphorylation of IP(3) receptor. EMBO J (2002) 21(1-2):83-92. doi:10.1093/emboj/21.1.83

243. Aiba Y, Yamazaki T, Okada T, Gotoh K, Sanjo H, Ogata M, et al. BANK negatively regulates Akt activation and subsequent B cell responses. Immunity (2006) 24(3):259-68. doi:10.1016/j.immuni.2006.01.002

244. Rieck M, Arechiga A, Onengut-Gumuscu S, Greenbaum C, Concannon P, Buckner JH. Genetic variation in PTPN22 corresponds to altered function of T and B lymphocytes. J Immunol (2007) 179(7):4704-10. doi:10.4049/ jimmunol.179.7.4704

245. Hasegawa K, Martin F, Huang G, Tumas D, Diehl L, Chan AC. PEST domain-enriched tyrosine phosphatase (PEP) regulation of effector/ memory T cells. Science (2004) 303(5658):685-9. doi:10.1126/science. 1092138

246. Schickel JN, Kuhny M, Baldo A, Bannock JM, Massad C, Wang H, et al. PTPN22 inhibition resets defective human central B cell tolerance. Sci Immunol (2016) 1(1):aaf7153. doi:10.1126/sciimmunol.aaf7153

247. Vang T, Congia M, Macis MD, Musumeci L, Orru V, Zavattari P, et al. Autoimmune-associated lymphoid tyrosine phosphatase is a gain-of-function variant. Nat Genet (2005) 37(12):1317-9. doi:10.1038/ng1673

248. Graham RR, Cotsapas C, Davies L, Hackett R, Lessard CJ, Leon JM, et al. Genetic variants near TNFAIP3 on 6q23 are associated with systemic lupus erythematosus. Nat Genet (2008) 40(9):1059-61. doi:10.1038/ng.200

249. Musone SL, Taylor KE, Lu TT, Nititham J, Ferreira RC, Ortmann W, et al. Multiple polymorphisms in the TNFAIP3 region are independently associated with systemic lupus erythematosus. Nat Genet (2008) 40(9):1062-4. doi:10.1038/ng.202

250. Adrianto I, Wen F, Templeton A, Wiley G, King JB, Lessard CJ, et al. Association of a functional variant downstream of TNFAIP3 with systemic lupus erythematosus. Nat Genet (2011) 43(3):253-8. doi:10.1038/ng.766

251. Tavares RM, Turer EE, Liu CL, Advincula R, Scapini P, Rhee L, et al. The ubiquitin modifying enzyme A20 restricts B cell survival and prevents autoimmunity. Immunity (2010) 33(2):181-91. doi:10.1016/j.immuni.2010.07.017

252. Chu Y, Vahl JC, Kumar D, Heger K, Bertossi A, Wojtowicz E, et al. B cells lacking the tumor suppressor TNFAIP3/A20 display impaired differentiation and hyperactivation and cause inflammation and autoimmunity in aged mice. Blood (2011) 117(7):2227-36. doi:10.1182/blood-2010-09-306019

253. Hovelmeyer N, Reissig S, Xuan NT, Adams-Quack P, Lukas D, Nikolaev A, et al. A20 deficiency in B cells enhances B-cell proliferation and results in the development of autoantibodies. Eur J Immunol (2011) 41(3):595-601. doi:10.1002/eji.201041313

254. Adrianto I, Wang S, Wiley GB, Lessard CJ, Kelly JA, Adler AJ, et al. Association of two independent functional risk haplotypes in TNIP1 with systemic lupus erythematosus. Arthritis Rheum (2012) 64(11):3695-705. doi:10.1002/art.34642

255. Nanda SK, Venigalla RK, Ordureau A, Patterson-Kane JC, Powell DW, Toth R, et al. Polyubiquitin binding to ABIN1 is required to prevent autoimmunity. J Exp Med (2011) 208(6):1215-28. doi:10.1084/jem.20102177

256. Manjarrez-Orduno N, Marasco E, Chung SA, Katz MS, Kiridly JF, Simpfendorfer KR, et al. CSK regulatory polymorphism is associated with systemic lupus erythematosus and influences B-cell signaling and activation. Nat Genet (2012) 44(11):1227-30. doi:10.1038/ng.2439

257. Floto RA, Clatworthy MR, Heilbronn KR, Rosner DR, MacAry PA, Rankin A, et al. Loss of function of a lupus-associated FcgammaRIIb polymorphism through exclusion from lipid rafts. Nat Med (2005) 11(10):1056-8. doi: $10.1038 / \mathrm{nm} 1288$

258. Blank MC, Stefanescu RN, Masuda E, Marti F, King PD, Redecha PB, et al. Decreased transcription of the human FCGR2B gene mediated by the $-343 \mathrm{G} / \mathrm{C}$ promoter polymorphism and association with systemic lupus erythematosus. Hum Genet (2005) 117(2-3):220-7. doi:10.1007/s00439005-1302-3

259. Kono H, Kyogoku C, Suzuki T, Tsuchiya N, Honda H, Yamamoto K, et al. FcgammaRIIB Ile232Thr transmembrane polymorphism associated with human systemic lupus erythematosus decreases affinity to lipid rafts and attenuates inhibitory effects on B cell receptor signaling. Hum Mol Genet (2005) 14(19):2881-92. doi:10.1093/hmg/ddi320

260. Tiller T, Kofer J, Kreschel C, Busse CE, Riebel S, Wickert S, et al. Development of self-reactive germinal center B cells and plasma cells in autoimmune $\mathrm{Fc}$ gammaRIIB-deficient mice. J Exp Med (2010) 207(12):2767-78. doi:10.1084/ jem. 20100171

261. Takai T, Ono M, Hikida M, Ohmori H, Ravetch JV. Augmented humoral and anaphylactic responses in Fc gamma RII-deficient mice. Nature (1996) 379(6563):346-9. doi:10.1038/379346a0

262. Xiang Z, Cutler AJ, Brownlie RJ, Fairfax K, Lawlor KE, Severinson E, et al. FcgammaRIIb controls bone marrow plasma cell persistence and apoptosis. Nat Immunol (2007) 8(4):419-29. doi:10.1038/ni1440

263. Niewold TB, Kelly JA, Flesch MH, Espinoza LR, Harley JB, Crow MK. Association of the IRF5 risk haplotype with high serum interferon-alpha activity in systemic lupus erythematosus patients. Arthritis Rheum (2008) 58(8):2481-7. doi:10.1002/art.23613

264. Feng D, Stone RC, Eloranta ML, Sangster-Guity N, Nordmark G, Sigurdsson S, et al. Genetic variants and disease-associated factors contribute to enhanced interferon regulatory factor 5 expression in blood cells of patients with systemic lupus erythematosus. Arthritis Rheum (2010) 62(2):562-73. doi:10.1002/ art.27223

265. Purtha WE, Swiecki M, Colonna M, Diamond MS, Bhattacharya D. Spontaneous mutation of the Dock2 gene in Irf5-/- mice complicates interpretation of type I interferon production and antibody responses. Proc Natl Acad Sci U S A (2012) 109(15):E898-904. doi:10.1073/pnas.1118155109

266. Yasuda K, Watkins AA, Kochar GS, Wilson GE, Laskow B, Richez C, et al. Interferon regulatory factor-5 deficiency ameliorates disease severity in the $\mathrm{MRL} / \mathrm{lpr}$ mouse model of lupus in the absence of a mutation in DOCK2. PLoS One (2014) 9(7):e103478. doi:10.1371/journal.pone.0103478

267. Thackray LB, Shrestha B, Richner JM, Miner JJ, Pinto AK, Lazear HM, et al. Interferon regulatory factor 5-dependent immune responses in the draining lymph node protect against West Nile virus infection. J Virol (2014) 88(19):11007-21. doi:10.1128/JVI.01545-14

268. Abelson AK, Delgado-Vega AM, Kozyrev SV, Sanchez E, Velazquez-Cruz R, Eriksson N, et al. STAT4 associates with systemic lupus erythematosus through two independent effects that correlate with gene expression and act additively with IRF5 to increase risk. Ann Rheum Dis (2009) 68(11):1746-53. doi:10.1136/ard.2008.097642

269. Liang Y, Pan HF, Ye DQ. Therapeutic potential of STAT4 in autoimmunity. Expert Opin Ther Targets (2014) 18(8):945-60. doi:10.1517/14728222.2014. 920325

270. Xu Z, Duan B, Croker BP, Morel L. STAT4 deficiency reduces autoantibody production and glomerulonephritis in a mouse model of lupus. Clin Immunol (2006) 120(2):189-98. doi:10.1016/j.clim.2006.03.009

271. Muto A, Ochiai K, Kimura Y, Itoh-Nakadai A, Calame KL, Ikebe D, et al. Bach2 represses plasma cell gene regulatory network in B cells to promote antibody class switch. EMBO J (2010) 29(23):4048-61. doi:10.1038/emboj. 2010.257

272. Morris DL, Sheng Y, Zhang Y, Wang YF, Zhu Z, Tombleson P, et al. Genomewide association meta-analysis in Chinese and European individuals identifies ten new loci associated with systemic lupus erythematosus. Nat Genet (2016) 48(8):940-6. doi:10.1038/ng.3603

273. Hipp N, Symington H, Pastoret C, Caron G, Monvoisin C, Tarte K, et al. IL-2 imprints human naive B cell fate towards plasma cell through ERK/ 
ELK1-mediated BACH2 repression. Nat Commun (2017) 8(1):1443. doi:10.1038/s41467-017-01475-7

274. Kim SJ, Gregersen PK, Diamond B. Regulation of dendritic cell activation by microRNA let-7c and BLIMP1. JClin Invest (2013) 123(2):823-33. doi:10.1172/JCI64712

275. Kim SJ, Schatzle S, Ahmed SS, Haap W, Jang SH, Gregersen PK, et al. Increased cathepsin $S$ in Prdm1-/- dendritic cells alters the TFH cell repertoire and contributes to lupus. Nat Immunol (2017) 18(9):1016-24. doi:10.1038/ni.3793

276. Cunninghame Graham DS, Morris DL, Bhangale TR, Criswell LA, Syvanen AC, Ronnblom L, et al. Association of NCF2, IKZF1, IRF8, IFIH1, and TYK2 with systemic lupus erythematosus. PLoS Genet (2011) 7(10):e1002341. doi:10.1371/journal.pgen.1002341

277. Carotta S, Willis SN, Hasbold J, Inouye M, Pang SH, Emslie D, et al. The transcription factors IRF8 and PU.1 negatively regulate plasma cell differentiation. J Exp Med (2014) 211(11):2169-81. doi:10.1084/jem. 20140425

278. Lee CH, Melchers M, Wang H, Torrey TA, Slota R, Qi CF, et al. Regulation of the germinal center gene program by interferon (IFN) regulatory factor 8/IFN consensus sequence-binding protein. J Exp Med (2006) 203(1):63-72. doi:10.1084/jem.20051450

279. Cai X, Huang W, Liu X, Wang L, Jiang Y. Association of novel polymorphisms in TMEM39A gene with systemic lupus erythematosus in a Chinese Han population. BMC Med Genet (2017) 18(1):43. doi:10.1186/s12881017-0405-8

280. Cortes M, Georgopoulos K. Aiolos is required for the generation of high affinity bone marrow plasma cells responsible for long-term immunity. J Exp Med (2004) 199(2):209-19. doi:10.1084/jem.20031571

281. Wang JH, Avitahl N, Cariappa A, Friedrich C, Ikeda T, Renold A, et al. Aiolos regulates B cell activation and maturation to effector state. Immunity (1998) 9(4):543-53. doi:10.1016/S1074-7613(00)80637-8

282. Russell L, John S, Cullen J, Luo W, Shlomchik MJ, Garrett-Sinha LA. Requirement for transcription factor Ets1 in B cell tolerance to self-antigens. J Immunol (2015) 195(8):3574-83. doi:10.4049/jimmunol.1500776

283. John SA, Clements JL, Russell LM, Garrett-Sinha LA. Ets-1 regulates plasma cell differentiation by interfering with the activity of the transcription factor Blimp-1. J Biol Chem (2008) 283(2):951-62. doi:10.1074/jbc. M705262200

284. Lu X, Zoller EE, Weirauch MT, Wu Z, Namjou B, Williams AH, et al. Lupus risk variant increases pSTAT1 binding and decreases ETS1 expression. Am J Hum Genet (2015) 96(5):731-9. doi:10.1016/j.ajhg.2015.03.002

285. Yang W, Shen N, Ye DQ, Liu Q, Zhang Y, Qian XX, et al. Genome-wide association study in Asian populations identifies variants in ETS1 and WDFY4 associated with systemic lupus erythematosus. PLoS Genet (2010) 6(2):e1000841. doi:10.1371/journal.pgen.1000841

286. Ols ML, Cullen JL, Turqueti-Neves A, Giles J, Shlomchik MJ. Dendritic cells regulate extrafollicular autoreactive $\mathrm{B}$ cells via $\mathrm{T}$ cells expressing Fas and
Fas ligand. Immunity (2016) 45(5):1052-65. doi:10.1016/j.immuni.2016. 10.005

287. Wu J, Metz C, Xu X, Abe R, Gibson AW, Edberg JC, et al. A novel polymorphic CAAT/enhancer-binding protein beta element in the FasL gene promoter alters Fas ligand expression: a candidate background gene in African American systemic lupus erythematosus patients. J Immunol (2003) 170(1):132-8. doi:10.4049/jimmunol.170.1.132

288. Shen N, Fu Q, Deng Y, Qian X, Zhao J, Kaufman KM, et al. Sex-specific association of X-linked toll-like receptor 7 (TLR7) with male systemic lupus erythematosus. Proc Natl Acad Sci U S A (2010) 107(36):15838-43. doi:10.1073/pnas.1001337107

289. Soni C, Wong EB, Domeier PP, Khan TN, Satoh T, Akira S, et al. B cellintrinsic TLR7 signaling is essential for the development of spontaneous germinal centers. J Immunol (2014) 193(9):4400-14. doi:10.4049/jimmunol. 1401720

290. Blasius AL, Arnold CN, Georgel P, Rutschmann S, Xia Y, Lin P, et al. Slc15a4, AP-3, and Hermansky-Pudlak syndrome proteins are required for toll-like receptor signaling in plasmacytoid dendritic cells. Proc Natl Acad Sci U S A (2010) 107(46):19973-8. doi:10.1073/pnas.1014051107

291. Sasawatari S, Okamura T, Kasumi E, Tanaka-Furuyama K, Yanobu-Takanashi R, Shirasawa $S$, et al. The solute carrier family $15 \mathrm{~A} 4$ regulates TLR9 and NOD1 functions in the innate immune system and promotes colitis in mice. Gastroenterology (2011) 140(5):1513-25. doi:10.1053/j.gastro.2011. 01.041

292. Kobayashi T, Shimabukuro-Demoto S, Yoshida-Sugitani R, Furuyama-Tanaka K, Karyu H, Sugiura Y, et al. The histidine transporter SLC15A4 coordinates mTOR-dependent inflammatory responses and pathogenic antibody production. Immunity (2014) 41(3):375-88. doi:10.1016/j.immuni.2014. 08.011

293. Baccala R, Gonzalez-Quintial R, Blasius AL, Rimann I, Ozato K, Kono DH, et al. Essential requirement for IRF8 and SLC15A4 implicates plasmacytoid dendritic cells in the pathogenesis of lupus. Proc Natl Acad Sci U S A (2013) 110(8):2940-5. doi:10.1073/pnas.1222798110

Conflict of Interest Statement: The authors declare that the research was conducted in the absence of any commercial or financial relationships that could be construed as a potential conflict of interest.

The reviewer RM and handling editor declared their shared affiliation.

Copyright $\odot 2018$ Malkiel, Barlev, Atisha-Fregoso, Suurmond and Diamond. This is an open-access article distributed under the terms of the Creative Commons Attribution License (CC BY). The use, distribution or reproduction in other forums is permitted, provided the original author(s) and the copyright owner are credited and that the original publication in this journal is cited, in accordance with accepted academic practice. No use, distribution or reproduction is permitted which does not comply with these terms. 